\begin{tabular}{|c|c|}
\hline 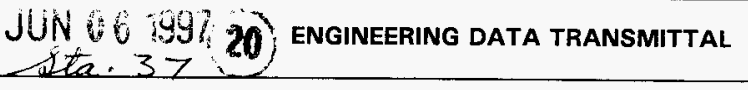 & 1. ЕDт 617612 \\
\hline
\end{tabular}

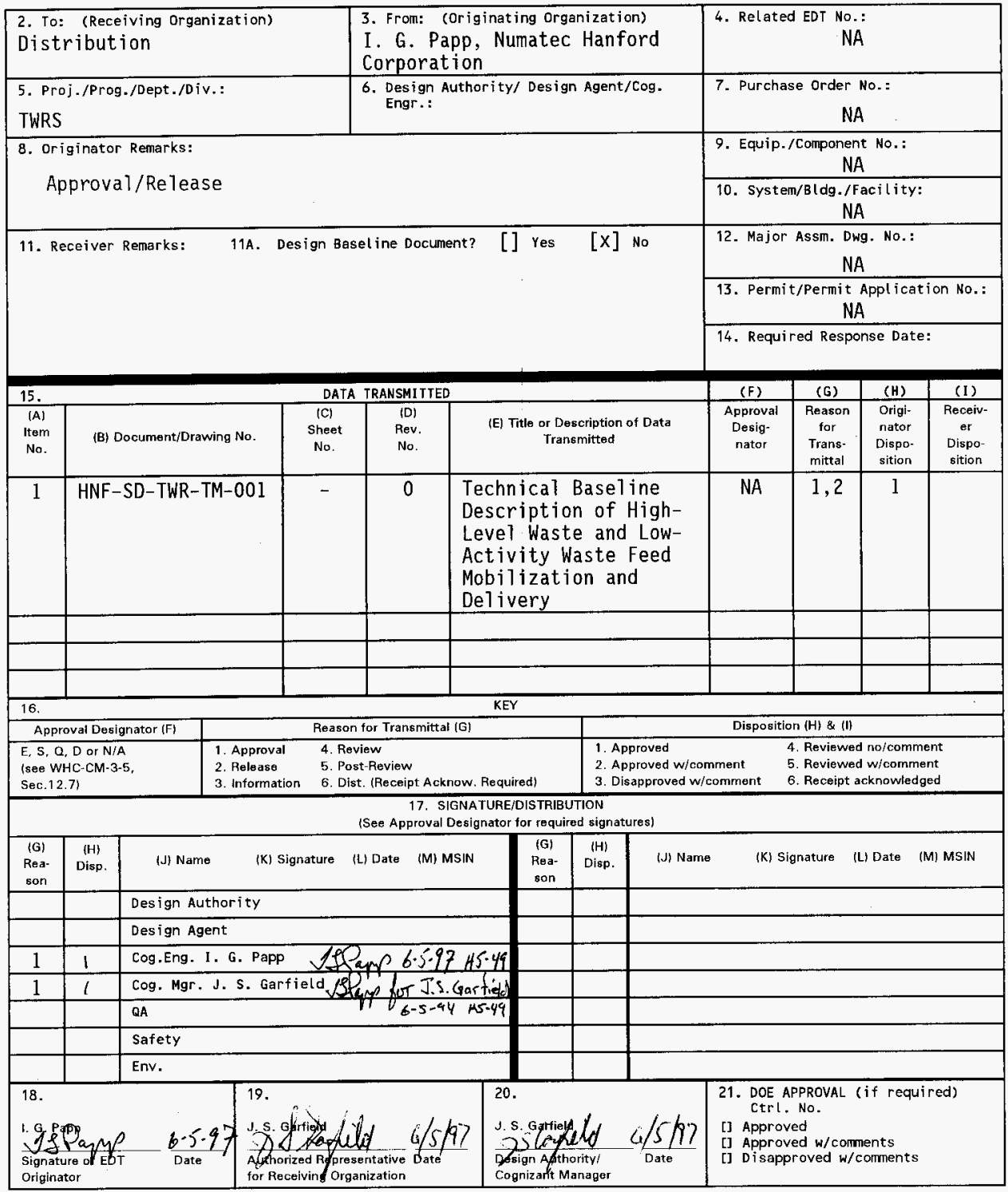




\title{
Technical Baseline Description of High-Level Waste and Low-Activity Waste Feed Mobilization and Delivery
}

\section{G. Papp}

Numatec Hanford Corporation, Richland, WA 99352

U.S. Department of Energy Contract DE-AC06-96RL 13200

\author{
EDT/ECN: $617612 \quad$ UC: 721 \\ Org Code: $8 C 451 \quad$ Charge Code: D6215 \\ B\&R Code: EW3130010 Tota7 Pages: 59
}

Key Words: HLW, LAW, feed mobilization, delivery, baseline

Abstract: This document is a compilation of information related to the high-level waste and low-activity waste feed staging, mobilization, and transfer/delivery issues. Information relevant to current Tank Waste Remediation System inventories and activities designed to feed the Phase I Privatization effort at the Hanford Site is included.

Discussions on the higher level Phase II activities are offered for a perspective on the interfaces.

\footnotetext{
TRADEMARK DISCLAIMER. Reference herein to any specific comercial product, process, or service by trade name, trademark, manufacturer, or otherwise, does not necessarily constitute or imply its endorsement, recommendation, or favoring by the United States Government or any agency thereof or its contractors or subcontractors.

Printed in the United states of America. To obtain copies of this document, contact: Document Control Services, P.0. BOX 950, Mailstop H6-08, Richland WA 99352, Phone (509) 372-2420; Fax (509) 376-4989.
}
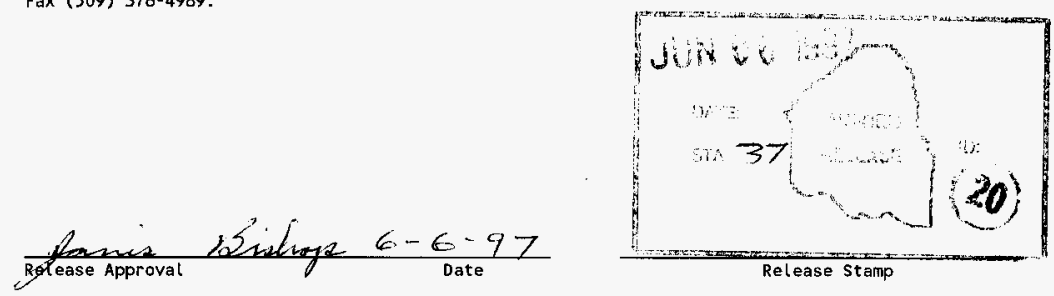


\section{TECHNICAL BASELINE DESCRIPTION OF HIGH-LEVEL WASTE AND LOW-ACTIVITY WASTE FEED MOBILIZATION AND DELIVERY}

June 1997

I. G. Papp

Numatec Hanford Corporation

Richland, Washington

Prepared for

U.S. Department of Energy

Richland, Washington 
HNF-SD-TWR-TM-001

Revision 0

This page intentionally left blank. 
HNF-SD-TWR-TM-001

Revision 0

CONTENTS

1.0 INTRODUCTION $\ldots \ldots \ldots \ldots \ldots \ldots \ldots \ldots \ldots \ldots \ldots \ldots \ldots \ldots$

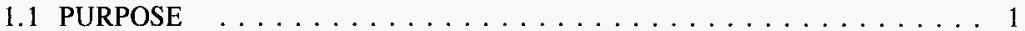

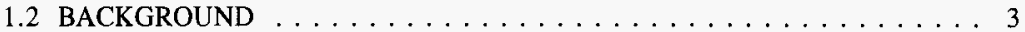

1.3 MID-LEVEL LOGIC $\ldots \ldots \ldots \ldots \ldots \ldots \ldots \ldots \ldots \ldots$

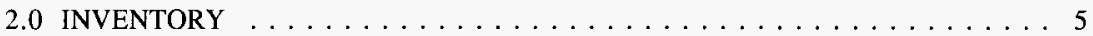

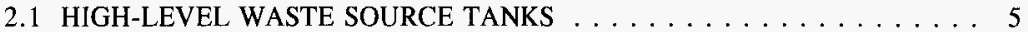

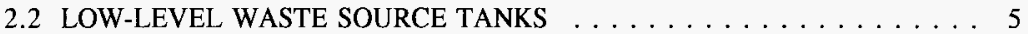

2.3 OPERATIONAL THRESHOLD FOR STORAGE/STAGING . . . . . . . 8

2.3.1 Operational Constraints of Existing Equipment $\ldots \ldots \ldots \ldots \ldots$

2.3.2 Operational Constraints on New Equipment . . . . . . . . . 9

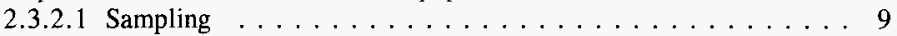

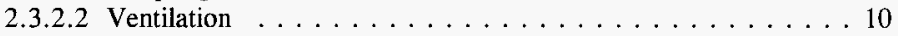

2.3.2.3 Heat Generation . . . . . . . . . . . . . 10

2.3.2.4 Minimum Required Heel . . . . . . . . . . . . . 10

2.4 FEEDS AND RETURNS FORM THE PRIVATE CONTRACTORS $\ldots \ldots \ldots 10$

2.5 BASE CASE CONSTRAINTS, REQUIREMENTS, AND ASSUMPTIONS . . 11

3.0 HARDWARE DESCRIPTION/INSTALLATION $\ldots \ldots \ldots \ldots \ldots \ldots \ldots$

3.1 MOBILIZATION OF TANK WASTE $\ldots \ldots \ldots \ldots \ldots \ldots \ldots \ldots \ldots$

3.2 TRANSFER OF TANK WASTE $\ldots \ldots \ldots \ldots \ldots \ldots \ldots \ldots \ldots$

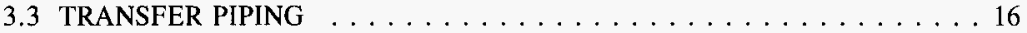

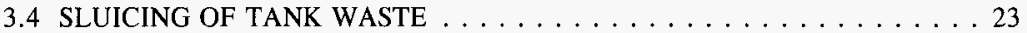

3.5 DILUTION AND/OR CHEMICAL ADJUSTMENT $\ldots \ldots \ldots \ldots . \ldots 23$

3.6 MONITOR AND CONTROL SYSTEM . . . . . . . . . . . . . 24

3.7 PROJECT ACTIVITY TO EQUIPMENT RELATIONSHIP . . . . . . . . . . . 24

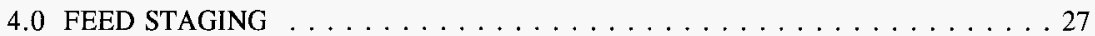

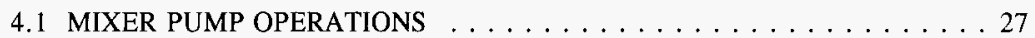

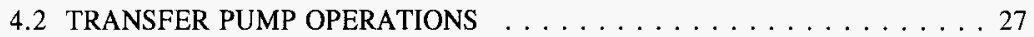

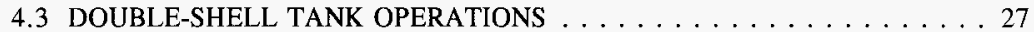

4.4 PIPING CONFIGURATION OPERATIONS $\ldots \ldots \ldots \ldots \ldots \ldots \ldots$

4.5 CHEMICAL ADJUSTMENT OPERATIONS . . . . . . . . . . 28

4.6 MONITOR AND CONTROL SYSTEM OPERATIONS $\ldots \ldots \ldots \ldots 28$

5.0 PROJECT DESCRIPTIONS AND INTERFACES . . . . . . . . . . . . . 29

5.1 SUPPORT AND INFRASTRUCTURE PROJECTS . . . . . . . . . . . . 29

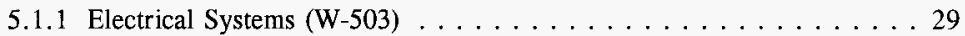

5.1 .2 Raw and Potable Water (W-504) . . . . . . . . . . . . . 29

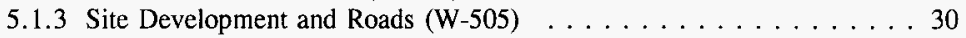

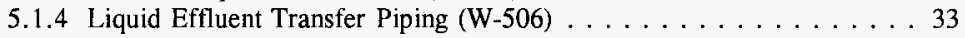

5.2 HIGH-LEVEL WASTE/LOW-ACTIVITY WASTE TRANSFER $\ldots \ldots \ldots 33$

5.2.1 Tank Farm Restoration and Safe Operations (W-314) . . . . . . . 33 


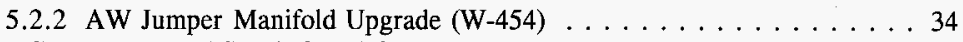

5.3 HIGH-LEVEL WASTE/LOW-ACTIVITY WASTE RETRIEVAL AND

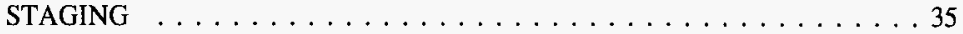

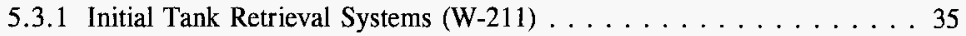

5.3.2 Tank 241-C-106 Retrieval (W-320) . . . . . . . . . . . . . . 37

5.3.3 Hanford Tank Initiative Retrieval Demonstration Project Retrieval

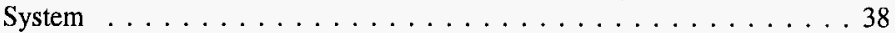

5.3.4 Tank Farms Ventilation Upgrade (W-030) . . . . . . . . . . . . 39

5.3.5 Mixer Pump System (W-151) . . . . . . . . . . . . . . . . 41

5.3.6 Immobilized Low-Level Waste Interim Storage (W-465) . . . . . . 41

5.3.7 Solidified High-Level Waste Interim Storage (W-464) . . . . . . . . 42

6.0 REFERENCES . . . . . . . . . . . . . . . . . . . . 43

APPENDIX

A - MID-LEVEL LOGIC $\ldots \ldots \ldots \ldots \ldots \ldots \ldots \ldots \ldots$ A-1 $\ldots \ldots \ldots$

B - PROJECT DOCUMENTATION LISTING . . . . . . . . . . B-1

\section{LIST OF FIGURES}

1. Simplified Logic Path for Low-Activity Waste and High-Level

Waste Safety/Environmental Related Activities. . . . . . . . . . . . 2

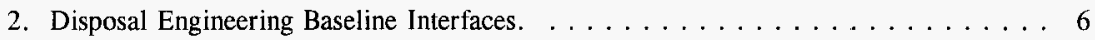

3. Tank Waste Remediation System Master Logic. . . . . . . . . . . . . 7

4. Phase I Retrieval Model Configuration. $\ldots \ldots \ldots \ldots \ldots \ldots \ldots \ldots$

5. Phase II Retrieval Model Configuration. . . . . . . . . . . . . 13

6. Tank Waste Remediation System Waste Transfer System Projects . . . . . . . 17

7. W-314 Phase I Project Transfer Line Requirements. . . . . . . . . . . . . . . 19

8. 200 East Tank Farm W-314 Waste Transfer Lines. . . . . . . . . . . . . . 21

9. Proposed Hierarchy Supporting Phase I Privatization. . . . . . . . . . . . 31 


\section{HNF-SD-TWR-TM-001 \\ Revision 0 \\ LIST OF TABLES}

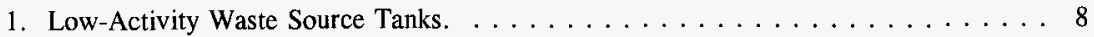

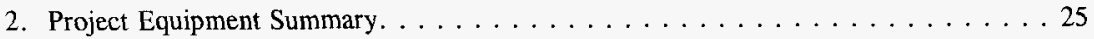




\section{LIST OF TERMS}

$\begin{array}{ll}\text { ALARA } & \text { As low as reasonably achievable } \\ \text { CC } & \text { Complex concentrate } \\ \text { CSB } & \text { Canister Storage Building } \\ \text { DCRT } & \text { Double-contained receiver tank } \\ \text { DN } & \text { Dilute non-complexant waste } \\ \text { DOE } & \text { U.S. Department of Energy } \\ \text { DQO } & \text { Data quality objective } \\ \text { DSS } & \text { Double-shell slurry } \\ \text { DSSF } & \text { Double-shell slurry feed } \\ \text { DST } & \text { Double-shell tank } \\ \text { ETF } & \text { Effluent Treatment Facility } \\ \text { HCS } & \text { Hot Conditioning System } \\ \text { HEPA } & \text { High-efficiency particulate air } \\ \text { HLAN } & \text { Hanford Local Area Network } \\ \text { HLW } & \text { High-level waste } \\ \text { HTI } & \text { Hanford Tanks Initiative } \\ \text { HTWOS } & \text { Hanford Tank Waste Operations Simulator } \\ \text { HVAC } & \text { Heating, ventilating, and air conditioning } \\ \text { ITRS } & \text { Initial Tank Retrieval Systems } \\ \text { LAW } & \text { Low-activity waste } \\ \text { LDMM } & \text { Leak detection, monitoring, and mitigation } \\ \text { LERF } & \text { Liquid Effluent Retention Facility } \\ \text { MCS } & \text { Monitor and Control System } \\ \text { NCAW } & \text { Neutralized Current Acid Waste } \\ \text { OSL } & \text { Operational specification limits } \\ \text { PUREX } & \text { Plutonium-uranium extraction } \\ \text { SNF } & \text { Spent Nuclear Fuel } \\ \text { TEDF } & \text { Treated Effluent Disposal Facility } \\ \text { TRS } & \text { Tank retrieval system } \\ \text { TWRS } & \text { Tank Waste Remediation System } \\ \text { UPS } & \text { Uninterruptible power supply } \\ & \end{array}$


HNF-SD-TWR-TM-001

Revision 0

\section{TECHNICAL BASELINE DESCRIPTION OF HIGH-LEVEL WASTE AND LOW-ACTIVITY WASTE FEED MOBILIZATION AND DELIVERY}

\subsection{INTRODUCTION}

This document is a compilation of information related to the high-level waste (HLW) and low-activity waste (LAW) feed staging, mobilization, and transfer/delivery issues. Information relevant to current Tank Waste Remediation System (TWRS) inventories and activities designed to feed the Phase I Privatization effort at the Hanford Site is included. Discussions on the higher level Phase II activities are offered for a perspective on the interfaces.

\subsection{PURPOSE}

This document is intended to provide a collection of relevant technical data that define the envelope of the LAW and HLW feed transfer and staging activities. An accumulation of technical data will aid in the identification of issues related to safety and permitting, and training.

Development of the projects associated with delivering feed to the Phase I Privatization Contractors has generated many supporting documents and project associated documents.

This document will present a high-level description of operations associated with feed staging activities. Inventory levels and constituent concentration will be represented with respect to technical issues that govern transfers and staging. Mechanical components are identified and constraints to operations with respect to transfers, mixing, monitoring, and sampling will be discussed as appropriate.

This document is intended to establish the baseline that is outlined in the logic path depicted in Figure 1. This logic path identifies specific activities necessary to provide an envelope for operations. This envelope allows operations to commence within an authorization basis for the defined feed staging and delivery activities.

The highlighted block in Figure 1 represents this document and illustrates the interaction this document has with related safety and environmental activities. 
HNF-SD-TWR-TM-001

Revision 0

Figure 1. Simplified Logic Path for Low-Activity Waste and

High-Level Waste Safety/Environmental Related Activities.

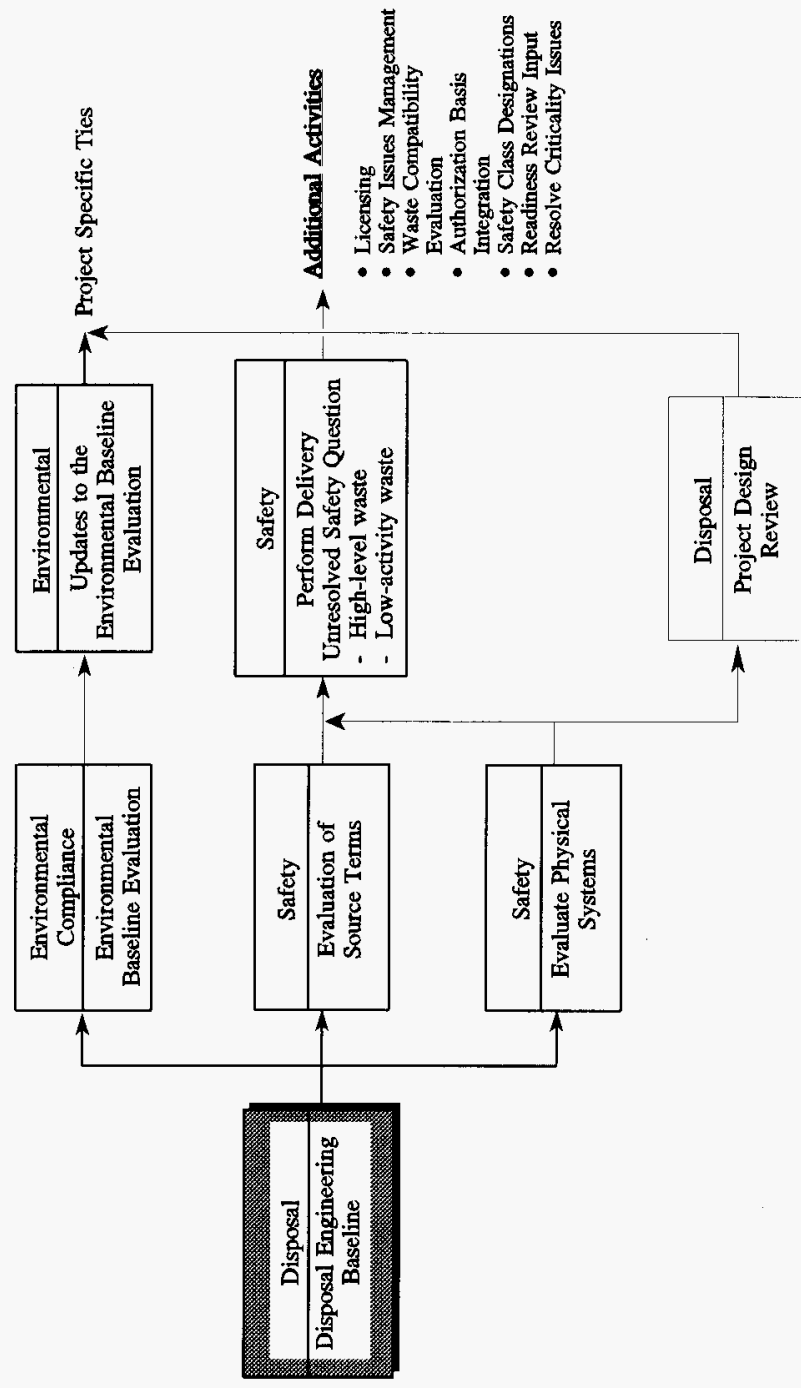

总 
Revision 0

\subsection{BACKGROUND}

Some issues that support information in this document are in various stages of development. As a result of this ongoing activity, certain information is still to be defined and included as supporting data. Updates to this document are anticipated as a result of this ongoing effort. Modeling of waste transfers are being developed and are identified in Section 2.0. This modeling will establish the mass balance flowsheet of the various staging activities required to support the Phase I feed delivery.

Figure 3 is provided to illustrate the higher level activities associated with Phase I and Phase II privatization activities. These activities include the following:

- Waste storage

- Retrieval

- Conditioning and Staging

- Processing

- Storage and Disposal.

\subsection{MID-LEVEL LOGIC}

The Mid Level Logic for the Initial Waste Feed Delivery is focused on activities across TWRS required to meet the 2002 date of delivering LAW and HLW to the private vendors for vitrification. The logic diagrams and associated narratives will be included as Appendix A. This view of logic therefore looks across all functions and projects within TWRS and their sequences, dependencies, and durations to deliver tank waste. This logic is being used as a communication tool and for the following:

- To evaluate the possibility of meeting the current, initial delivery date

- To discuss a critical schedule path through the activities

- To identify schedule changes required to meet the initial delivery date and take some redirection actions based on this knowledge

- To provide a common forum for projects to discuss interfaces and interdependencies.

A Technical Basis Review form has been developed to document the basis for the activities shown on the logic diagrams. Included for each activity is a technical point of contact, identification of a responsible organization along with the accountable manager, predecessor and successor activities, schedule information, technical basis with references, enabling assumptions, functional requirements, trade studies, decisions made and required to make, and risk information. 
HNF-SD-TWR-TM-001

Revision 0

This page intentionally left blank. 


\section{HNF-SD-TWR-TM-001 \\ Revision 0}

\subsection{INVENTORY}

The inventory basis for feed is derived from tank characterization reports for individual tanks in TWRS. These characterization reports are used as the source of information to derive a standard inventory of tank waste and a report entitled Standard Inventories of Chemicals and Radionuclides in Hanford Site Tank Wastes (Kupfer et al. 1997) represents the sum of all chemical and radiochemical components presently stored in Hanford tanks. Figure 2 represents a simplified illustration of how the characterization (best-basis inventory) is fed to the Hanford Tank Waste Operations Simulator (HTWOS). The HTWOS is a computer model that aids in the scheduling sequences of staging vitrification feeds.

\subsection{HIGH-LEVEL WASTE SOURCE TANKS}

The sludge identified for treatment as HLW will originate from Neutralized Current Acid Waste (NCAW) tanks 241-AZ-101 and 241-AZ-102, as well as high-heat sludge from 241-C-106 (retrieved into 241-AY-102). A discussion of tanks 241-AZ-101, 241-AZ-102, and 241-AY-102 feed basis characterization is contained in the Phase I High-Level Waste Pretreatment and Feed Staging Plan (Manuel et al. 1996).

Sludge characterization is also presented in TWRS Process Flowsheet (Orme 1995) as a global inventory. This global inventory accounts for the individual characterization of tanks applied to a calculated model of the entire inventory. The Phase I High Level Waste Pretreatment and Feed Staging Plan (Manuel et al. 1996) makes certain changes to the TWRS flowsheet with respect to the overall inventories and solubility data. These changes should be reflected in future revisions of the TWRS flowsheet document as applicable.

Estimated feed to the HLW vendor will be further refined and documented in the TWRS Operation and Utilization Plan (Kirkbride 1997a) currently in draft form. This document is scheduled for release in August 1997.

\subsection{LOW-LEVEL WASTE SOURCE TANKS}

Double-shell tanks (DSTs) identified as Phase I LAW source feed (Certa et al. 1996) under envelope A, B, and C as identified in Part I, Section C, Specification 7 of Contract DE-AC06-RL13309 (DOE RL 1996a) and DE-AC06-RL13308 (DOE RL 1996b) are listed in Table 1 . 


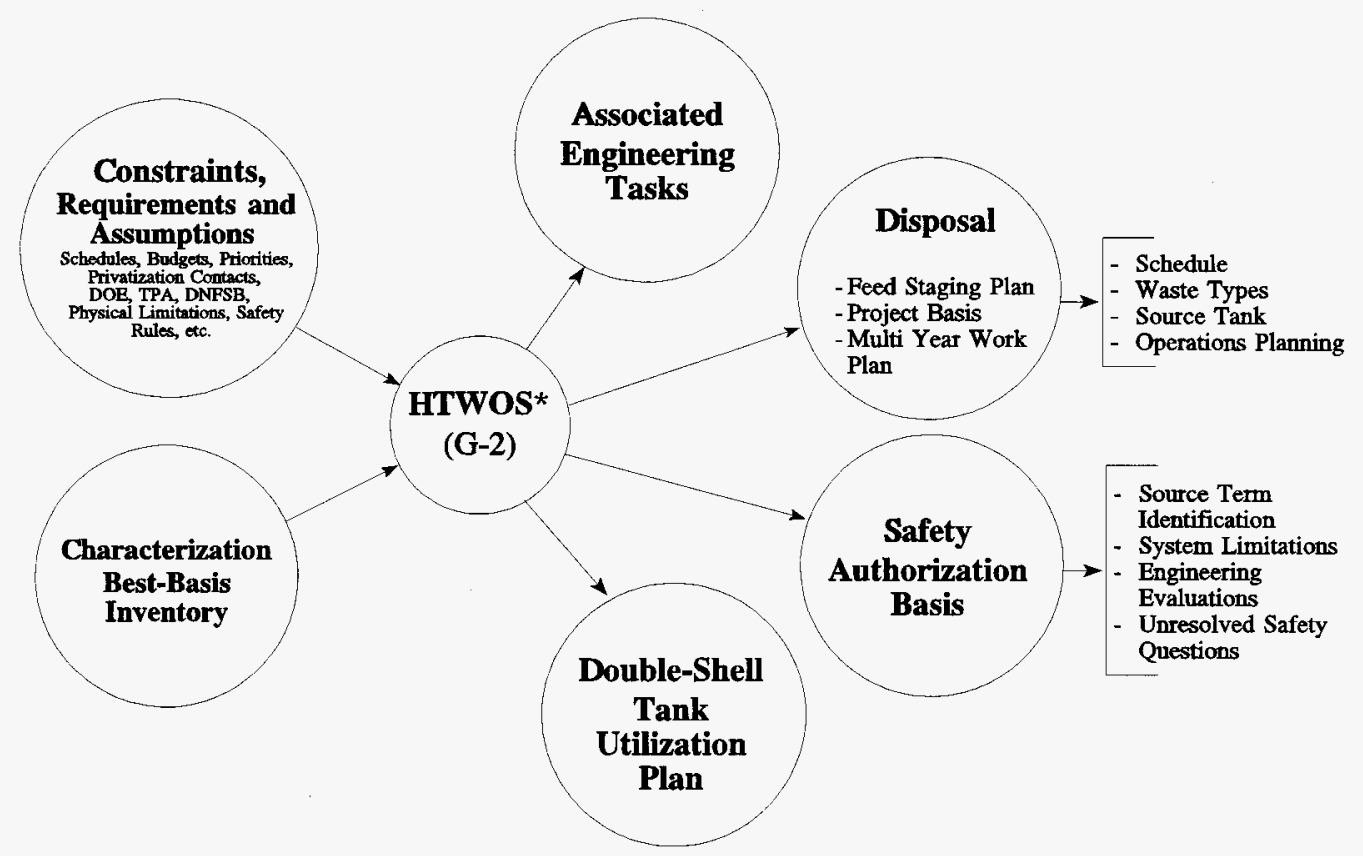


Feed Delivery

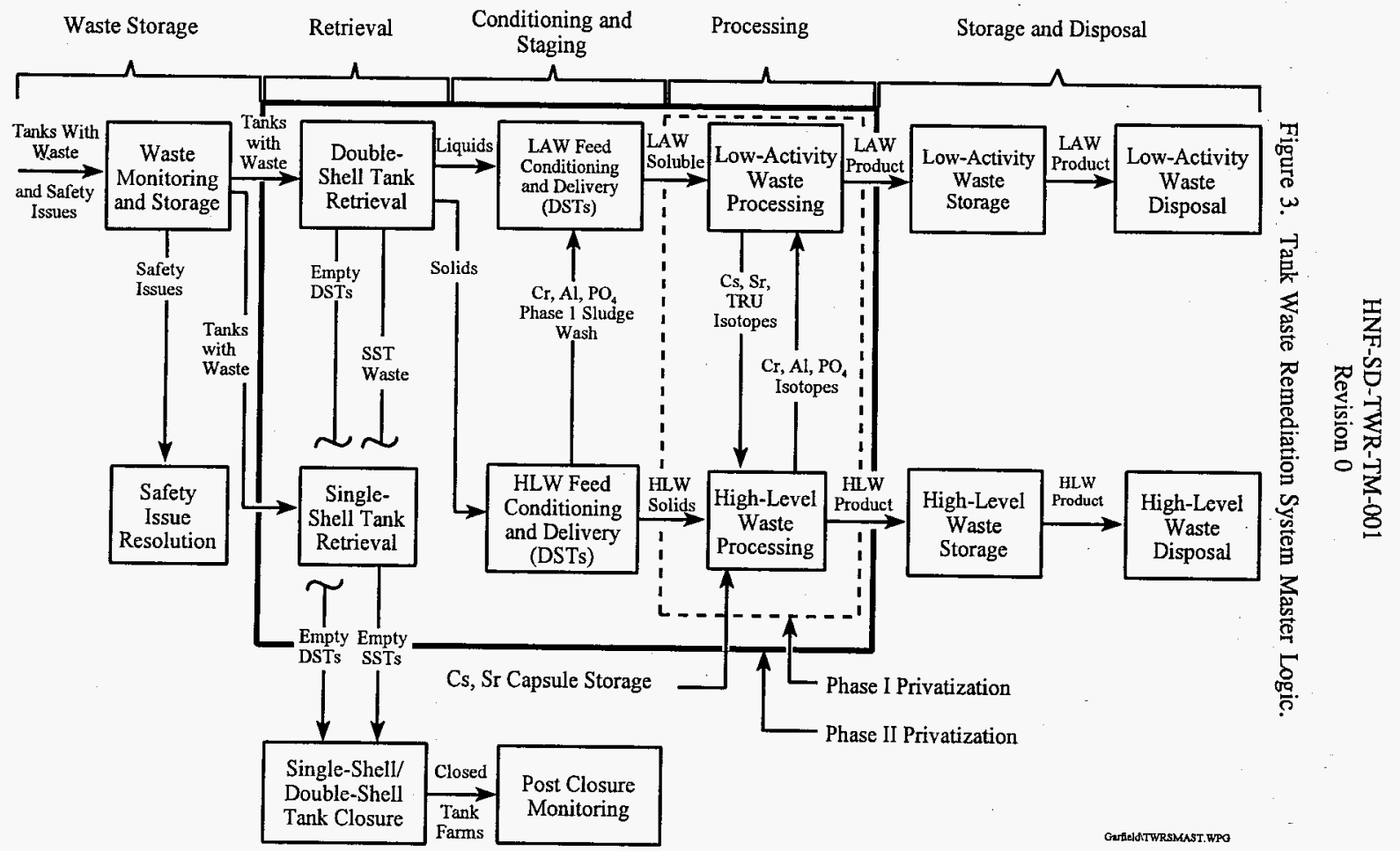


HNF-SD-TWR-TM-001

Revision 0

Table 1. Low-Activity Waste Source Tanks.

\begin{tabular}{|l|l|c|}
\hline \multicolumn{1}{|c|}{ Tank } & \multicolumn{1}{|c|}{ Waste type } & Waste envelope \\
\hline 241-AN-102 & Complex Concentrate (CC) & C \\
\hline 241-AN-103 & Double-Shell Slurry Waste (DSS) & A \\
\hline 241-AN-104 & Double-Shell Slurry Feed Waste (DSSF) & A \\
\hline 241-AN-105 & DSSF & A \\
\hline 241-AN-106 & CC & C \\
\hline 241-AN-107 & CC & C \\
\hline 241-AP-104 & Dilute Non-Complexant Waste (DN) & A \\
\hline 241-AP-106 & DSSF & A \\
\hline 241-AP-107 & CC & C \\
\hline 241-AW-101 & DSSF & A \\
\hline 241-AY-101 & Neutralized Current Acid Waste (NCAW) & B \\
\hline
\end{tabular}

The waste types depicted in Table 1 above reflect the waste inventory that will be present as identified in the Low-Level Waste Feed Staging Plan (Certa et al. 1996). The feed to the Phase I Private Contractors will be represented by predictions defined in the TWRS Operation and Utilization Plan (Kirkbride 1997a).

\subsection{OPERATIONAL THRESHOLD FOR STORAGE/STAGING}

Constraints that surround the operations of the retrieval and mobilization effort are based in part on technical limitations associated with individual components of the respective systems that are not safety driven. The constraints that are safety related are candidates for re-analysis.

The existing DST systems have been evaluated for engineering limitations and these are documented in current operating specification documents listed below. Constraints that limit operations of existing equipment will only be referenced in this document unless that limitation is to be revisited.

\subsubsection{Operational Constraints of Existing Equipment}

Operational constraints that exist for DSTs and SSTs can be found, in part, in operating specifications for the respective tanks. 


\section{HNF-SD-TWR-TM-001 \\ Revision 0}

Operating specifications for DSTs (AN, AP, AW, AY, AZ, and SY) are contained in Unclassified Operating Specifications for the 241-AN, AP, AW, AY, AZ, and SY Tank Farms, OSD-T-151-00007 (PHMC 1996a). This specification covers dilute waste operations in these farms. Operating Specifications for Aging-Waste Operations in 24I-AY and 241-AZ, OSD-T-151-00017 (PHMC 1996c) covers the aging waste operations in 241-AY and 241-AZ farms.

Operating specifications for SSTs are contained in Unclassified Operating Specifications for Single-Shell Waste Storage Tanks, OSD-T-151-00013 (PHMC 1996b). Specifications for watch list tanks are contained in Operating Specifications for Aging-Waste Operations in 241-AY and 241-AZ, OSD-T-151-00030 (PHMC 1997). Other specifications exist with respect to ventilation systems and transfer line pressure testing (to ensure line integrity), but the intent here is to identify specific parameters related to constituents found in tanks as well as physical parameters. Watch list tank specifications define constraints to operations related to sampling, transfer, in-tank inspections, etc. These watch list tanks currently include hydrogen/flammable gas tanks, organic tanks, and high heat tanks. Watch list tanks are listed in Waste Tank Summary Report for Month Ending XX-XX-XX (Xs denote a living document), HNF-EP-0182-106 (Hanlon 1997).

Operation specifications for DSTs and SSTs include but are not limited to parameters such as tank content composition, waste levels, dome loading, waste temperatures, vapor space pressures, gaseous effluents concentrations, and process transfers. Also, waste chemistry notification limits identified in the operating specifications that relate to criticality, heat generation, fuel concentration, organic salts, ferrocyanide, organic liquid, etc., may trigger engineering evaluations against watch list criteria.

The feed predictions defined in the TWRS Operation and Utilization Plan (Kirkbride 1997a) currently in draft form (as noted in Section 2.1 above) will be scrutinized by engineering review against applicable technical restrictions. This engineering evaluation will ensure safe limits and conditions are met in all tanks during staging activities.

\subsubsection{Operational Constraints on New Equipment}

This section will, in part, define the technical limits relevant to tank storage and/or transfer and the requirements to satisfy those limits are met. Existing equipment that will be utilized during the feed staging operations will require evaluation against technical issues outside of the current operational specification limits (OSLs).

2.3.2.1 Sampling. Sampling requirements are the results of decisions arrived at by the application of Data Quality Objectives (DQOs). The Waste Feed Staging Data Quality Objectives Activity Plan (Kirkbride 1997b) defined the strategy for preparing DQOs related to TWRS waste feed staging and delivery. The DQO process has been applied (as an illustrated example) to Feed Delivery Mid-Level Logic items L 53, L59, and H33. This process contains 7 steps ranging from stating the problem to optimizing the design for obtaining data. 
Problem-specific DQOs for Phase I feed staging and delivery have identified specific items cited on the mid-level logic diagrams to which the process may be applied.

Sampling requirements will be developed as the requirements are identified through this DQO process. A base case is offered (Kirkbride 1997b) for determining the sampling requirements of any individual tank.

2.3.2.2 Ventilation. Mixer pump operation will impart an additional heat loading to the affected tank waste and necessitates an evaluation of the ventilation capability for the tank. An analysis, which is reported in the Double-Shell Tank Retrieval System Alternative Generation Analysis Support (Salzano et al. 1997), indicates that ventilation requirements can be maintained within the operating specification document requirements by administrative controls.

2.3.2.3 Heat Generation. Decay heat maximums allowed by operational specifications limit the amount of heat generated by the waste stored in a specific tank. Heat limits are in place to prevent tank waste from boiling (in the case of AN, AP, AW, and SY). The mentioned tank ventilation systems were not designed to accommodate boiling within the tank and no factor for the added burden on the ventilation system is accounted for.

Again administrative controls are required on the mixer pump operation to limit the tank waste temperature and ensure the temperature increase per day limit are maintained.

2.3.2.4 Minimum Required Heel. Consideration of the residual heel in a given tank must be applied to the internal pressure of the tank vapor space. Ventilation systems are designed to pull a vacuum on the vapor space and thus require a minimum heel to remain on the tank bottom while the ventilation system is in operation.

Consideration of the transfer operations will require addressing this issue specifically in tanks equipped with a variable height suction mechanism.

\subsection{FEEDS AND RETURNS FORM THE PRIVATE CONTRACTORS}

The interface control document between the Private Contractors and the U.S. Department of Energy (DOE) is in the development phase. The physical interface between the Private Contractors and the TWRS is through the central pump pits located at 241-AP-106 and - 108 tanks. One of these tanks is assigned to each contractor with separate feed and return piping for each contractor. No piping interconnects the contractors facilities outside of the AP tanks.

TWRS Privatization Contracts (DOE-RL 1996a,b) outline the requirements for returns to the DOE. Specification 9 under Section C. 6 of the referenced contracts identify requirements for returns. The requirements outlined under specification 9 include issues related to product composition, composition limits, criticality, separable organics, heat 
generation, physical parameters, scaling, and chemical stability to prevent exothermic reactions.

Interface descriptions are identified by the above referenced contracts. There are 22 identified interface description activities. These issues include in part Non Routine HL Solid Waste (ID 13), Non Dangerous Non Radioactive Liquid Effluents (ID 5), Radioactive Dangerous Liquid Effluents (ID 6), Strontium/Transuranic/Entrained Solids (ID 16), and Waste Feed Tanks (ID 21). Many other issues are also addressed that include electrical, sanitary water, and raw water utilities.

Projects that allow for the transfer of streams identified in the TWRS Privatization Contracts are discussed in Section 5.0.

\subsection{BASE CASE CONSTRAINTS, REQUIREMENTS, AND ASSUMPTIONS}

The integrated base case constraints, requirements and assumptions appendix of the TWRS Operation and Utilization Plan (Kirkbride 1997a) provides the assumptions for the LAW and HLW feed staging plans, the Initial Retrieval Sequence and Blending Strategy (Penwell 1996), and the TWRS Privatization Process Technical Baseline (Orme 1996). The constraints, requirements and assumptions are discussed with regard to both Phase I and Phase II retrieval activities. Figure 4 is provided as a depiction of the Phase I retrieval modeling activities. Figure 5 is provided to illustrate the Phase II retrieval model activities. 
Figure 4. Phase I Retrieval Model Configuration.

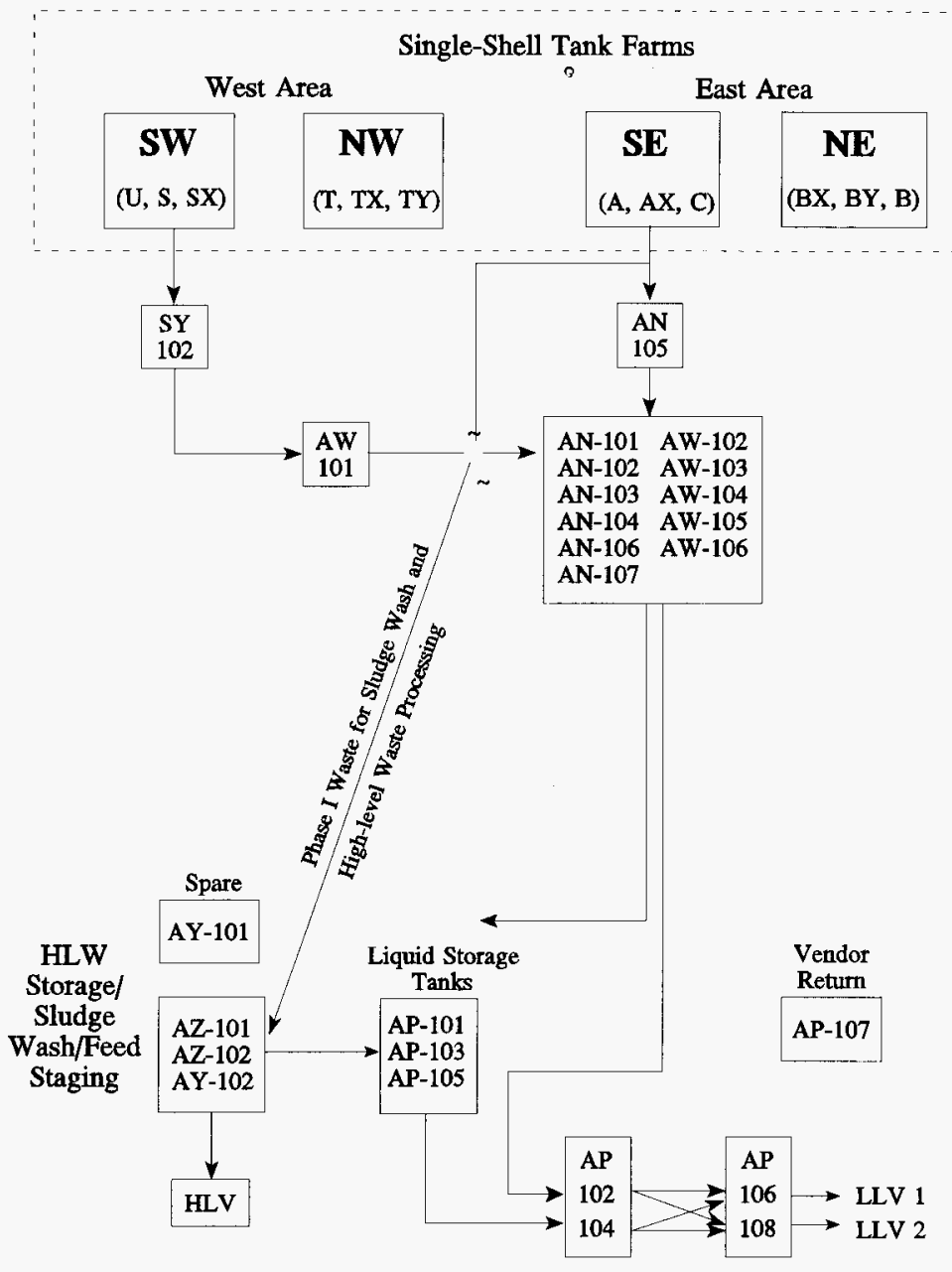

HLV = High-Level Vitrification

LLV $=$ Low-Level Vitrification

Penwell/Phase1.WPG 
HNF-SD-TWR-TM-001

\section{Revision 0}

Figure 5. Phase II Retrieval Model Configuration.

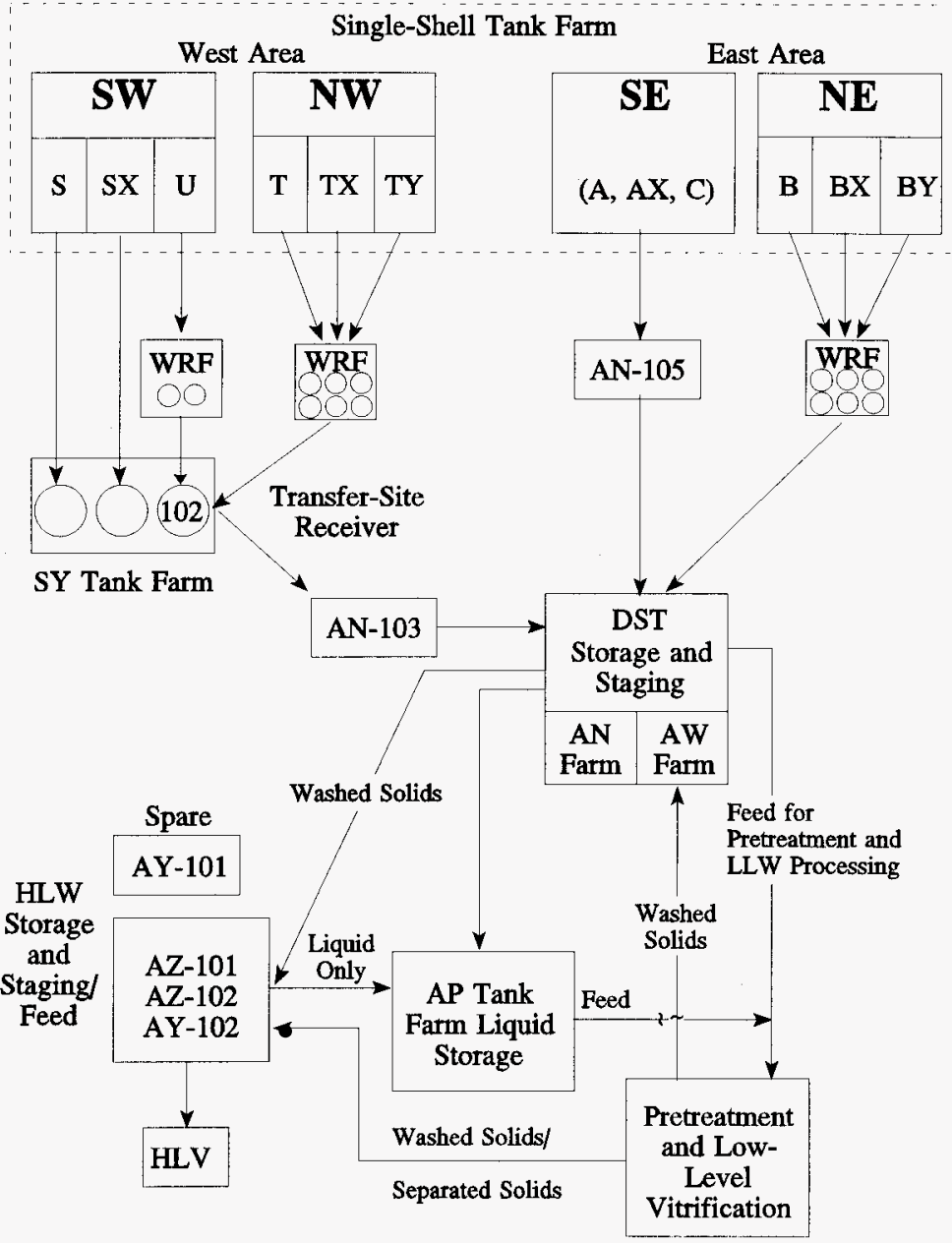

1 simultaneous retrieval per farm

HLV - High-Level Vitrification

3 per quadrant except for SE quadrant

LLW = Low-Level Waste

1 retrieval into any single tank at any time

PenwellyPhase 2.WPG 
HNF-SD-TWR-TM-001

Revision 0

This page intentionally left blank. 
HNF-SD-TWR-TM-00I

Revision 0

\subsection{HARDWARE DESCRIPTION/INSTALLATION}

Hardware will be installed to accommodate the transport and staging of solids and liquids from DSTs. These operations will require basic functions to be employed on all the tanks listed in Sections 2.1 and 2.2 above. The functions include:

- Mobilization of Tank Waste

- Transfer of Tank Waste

- Dilution and/or Chemical Adjustment of Tank Waste (dissolution of waste)

- Air Handling (ventilation) of Tank Waste.

\subsection{MOBILIZATION OF TANK WASTE}

DSTs that contain solids will require equipment to fluidize the solids in an effort to retrieve and transfer them to the Phase I Private Contractors. The three basic methods to achieving mobilization that are being considered are installation of mixer pump system, sonic probe system, and sluicing system.

The mixer pump system is outlined in Double-Shell Tank Retrieval System Alternative Generation Analysis Support (Salzano et al. 1997). There are two options currently being investigated. These are to either mount two or one mixer pumps in an individual tank.

Mounting pumps would either be accomplished by installation in the off center $107-\mathrm{cm}$ (42-in.) (5A, 5B) risers or in the 107-cm (42-in.) (11) riser in the central pump pit. Pump design is based on a $300 \mathrm{hp}$ motor, $1,200 \mathrm{rpm}, 39,364 \mathrm{~L} / \mathrm{min}(10,400 \mathrm{gal} / \mathrm{min})$ operational flow and $16.46 \mathrm{~m}(54 \mathrm{ft})$ total head discharge pressure.

Installation of pumps is based on service with highly radioactive waste. Shielding is provided by coverblock assemblies and shield plugs. Decontamination is achieved with spray rings and safe maintenance and operating practices.

A turntable assembly is provided on the upper motor portion of each pump that allows for the pump assembly to be rotated. This rotation allows nozzles on the discharge of the pump to be positioned toward all areas of the tank.

Mixer pumps are equipped with an Adjustable Frequency Controller. This is a variable speed drive mechanism to control the speed of the motor by changing the frequency of the power supply.

Mixer pumps are positioned in the tank at varying depths according to the waste volume in the tank. These pumps do not lift waste out of the associated tank and would not subject workers to additional radiation exposure while in a lifted position. 
HNF-SD-TWR-TM-001

Revision 0

\subsection{TRANSFER OF TANK WASTE}

Waste transfer pumps operate in a similar fashion to the mixer pumps described above. The pumps are lowered into position according to the depth requirements of the particular DST volume being transferred. The transfer pumps would operate with a waste filled transfer column that requires variable shielding consideration at different raised positions.

The transfer pump would be mounted in the central pump pit of each respective tank and be equipped with an adjustable frequency controller (for control of pump speed). Transfer pumps are located on a $30.48-\mathrm{cm}$ (12-in.) riser of each respective tank. This riser is located within a concrete encasement for shielding.

The pumping characteristics of the transfer pump are represented on the basis of a variable speed motor that operates within the range of $900 \mathrm{rpm}$ to $3,600 \mathrm{rpm}$. At the $3,600 \mathrm{rpm}$ speed the pump is expected to deliver $530 \mathrm{~L} / \mathrm{min}(140 \mathrm{gal} / \mathrm{min})$ at $122 \mathrm{~m}(400 \mathrm{ft})$. Transfer routes are discussed in Section 3.3.

\subsection{TRANSFER PIPING}

Transfer lines are depicted in Figures 6, 7, and 8. Figure 6 represents an overview of the interface relationship between the various projects (W-314, W-211, W-320, W-058, W-030, W-087, and W-454). Figure 7 represents an overview of Project W-314 and its relationship with existing TWRS transfer paths and some of the planed W-211 components. Figure 8 is a more detailed depiction of the piping interfaces. Figure 8 identifies specific tie-in points that identify the transfer paths.

Waste transfer to the Private Contractors will be accomplished by using a combination of existing waste transfer lines and new lines provided by Projects W-211 and W-314. The waste transfer system will be configured as shown in Figure 8.

The Phase I Privatization will be processing waste that is currently stored in the 200-E DST tank farm, hereafter referred to as the A-Farm Complex. Project W-314 will be installing new $7.62-\mathrm{cm}(3-\mathrm{in}$.) waste transfer lines that will originate at the $241-\mathrm{AN}-\mathrm{B}$ valve pit. This line will be routed to a $241-\mathrm{AZ}-102$ process pit. From the $\mathrm{AZ}$ process pit another line will be routed to AX-B valve pit. From the AX-B valve pit another line will be routed to the A-B valve pit. Along with the addition of the new transfer lines mentioned, the process $\mathrm{pits} / \mathrm{valve}$ pits will be upgraded with new jumper manifolds that will facilitate waste transfer route changes. There will also be new 7.62-cm (3-in.) transfer lines added in the $\mathrm{AZ}$ and $\mathrm{AY}$ tank farms to facilitate the transfer of sludges. 


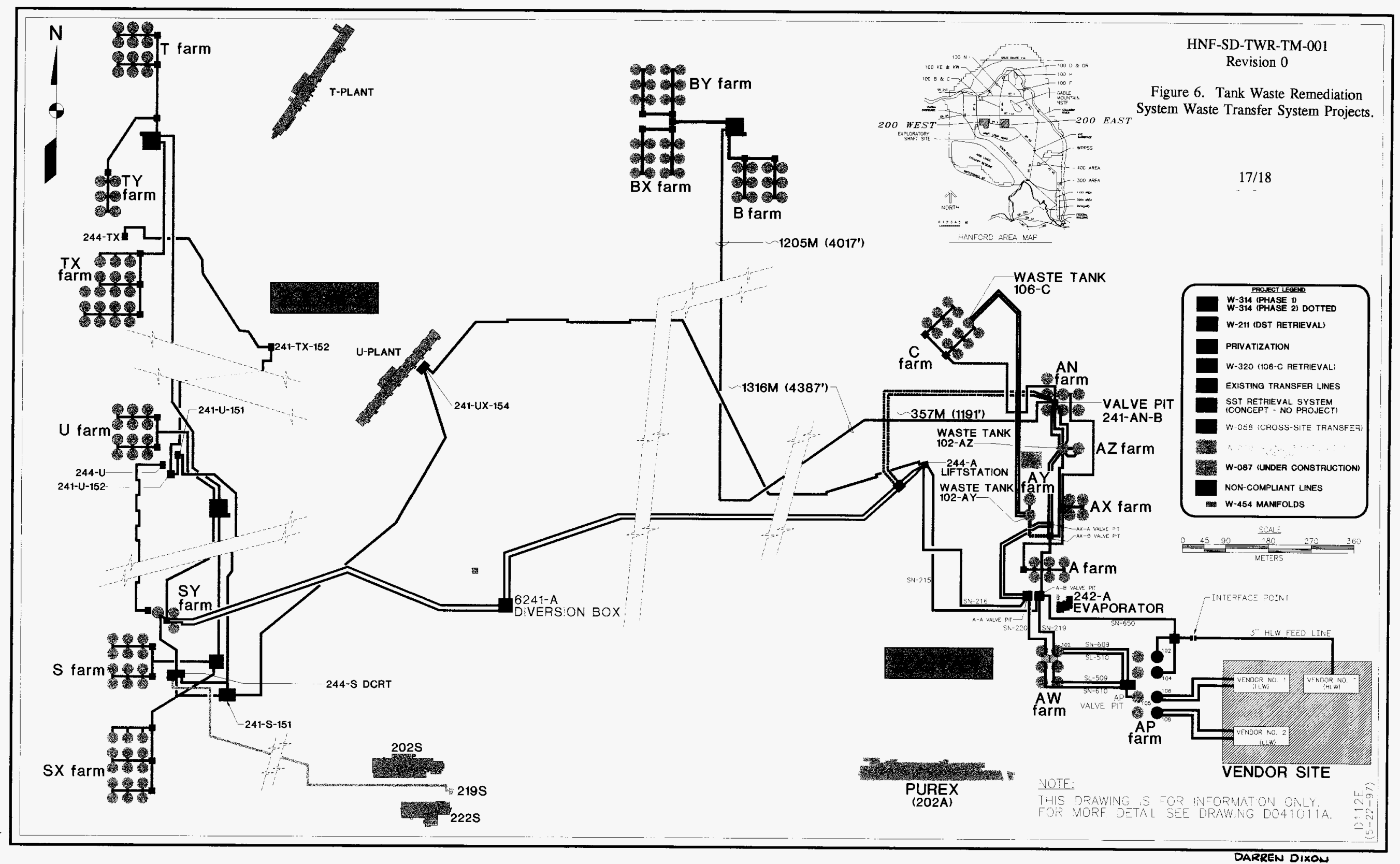


Revision 0

Figure 7. W-314 Phase I Project Transfer Line Requirements.

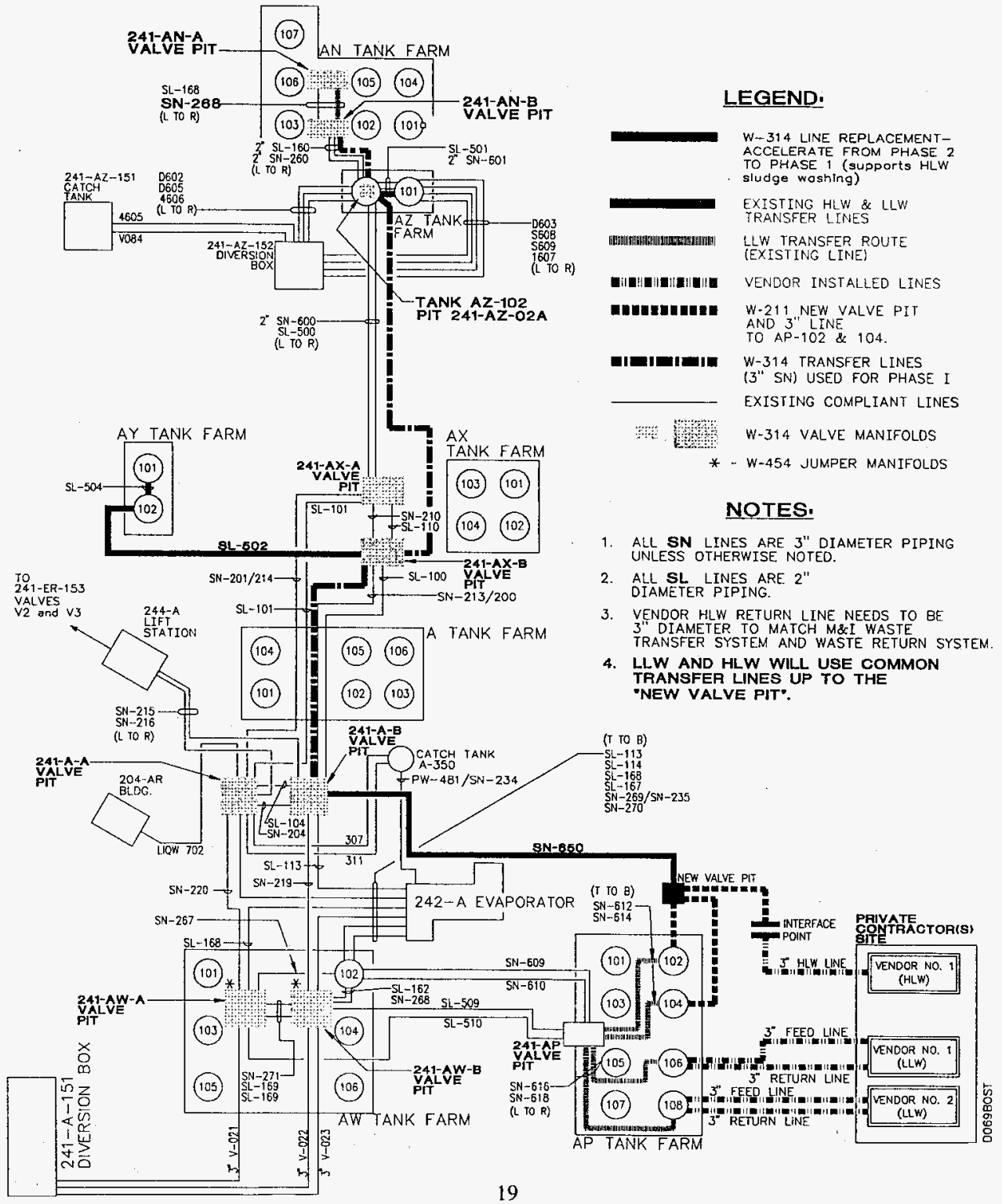


HNF-SD-TWR-TM-001

Revision 0

This page intentionally left blank. 


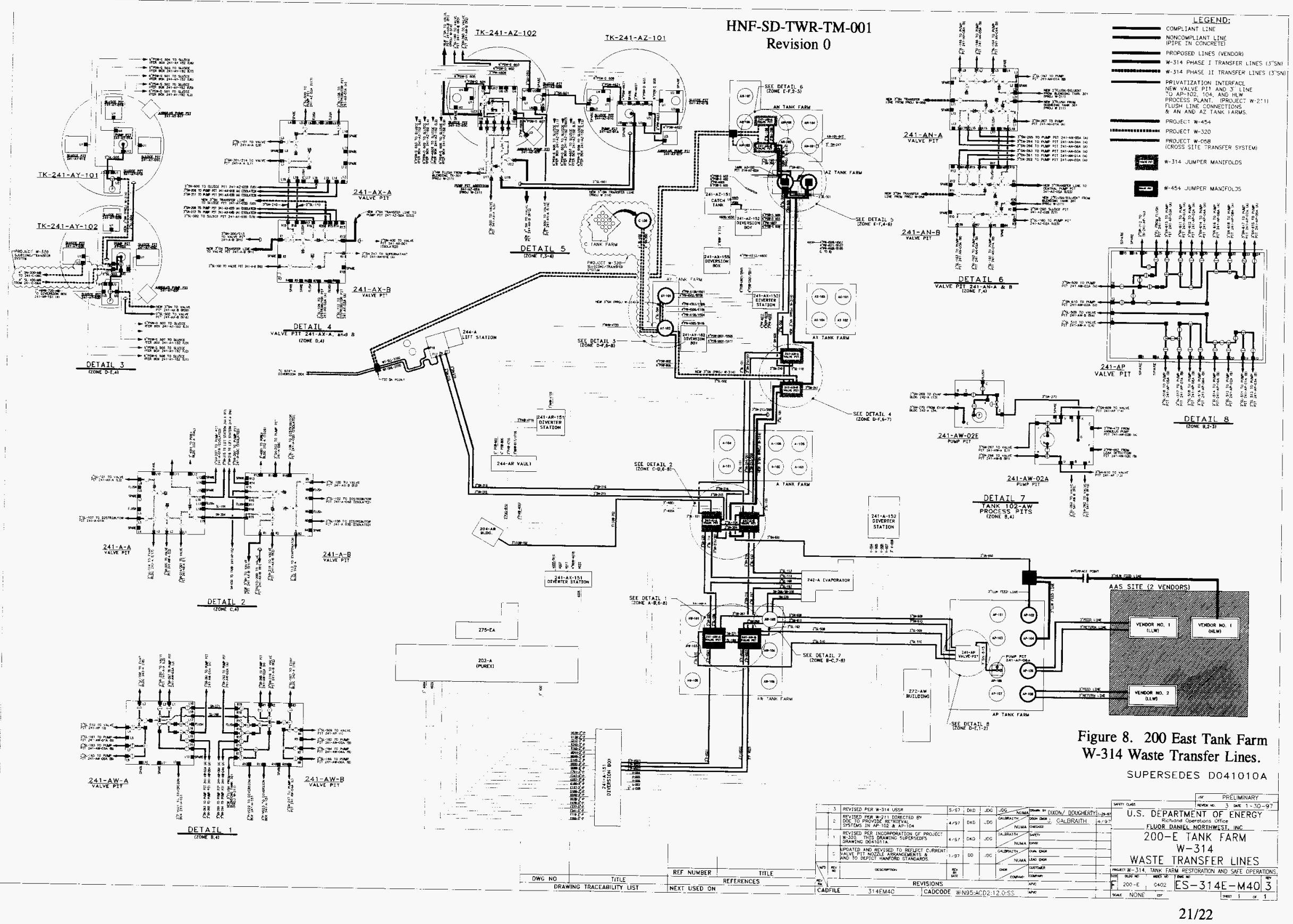


HNF-SD-TWR-TM-001

Revision 0

Project W-211 will modify the existing SN-650 waste transfer line that currently terminates at 241-AP-102. A new valve/diversion pit will be added that will be equipped with a jumper manifold for routing waste to 241-AP-102, 241-AP-104, or routing HLW to the Private Contractors vitrification processing facility.

All transfer of waste will be made through the 7.62-cm (3-in.) piping system, and as stated above, will be accomplished by using existing tank farm systems plus new piping provided by $\mathrm{W}-211$ and $\mathrm{W}-314$.

\subsection{SLUICING OF TANK WASTE}

The sluicing system is presented as an option to the mixer pump. This system employs a pressurized spray that dislodges and mobilizes solids in a tank. Once solids are suspended in solution they are transferred out with a slurry pump.

The sluice and slurry pump systems are made up of two pumps in series. A 40-hp submersible pump suspended from a winch system hangs from the dome of the tank into the waste. The winch allows the pump to be raised or lowered as necessary. This pump assembly requires a $107-\mathrm{cm}(42-\mathrm{in}$.) riser and would be located in riser no. 11 of the central pump pits. The submersible pump feeds a 250 -hp, variable speed centrifugal booster pump. The size of the booster pumps is too large to be located in the AN-Tank farm central pump pits; therefore, new booster pump pits are required. The booster pump raises the transfer fluid pressure to the level necessary to transfer the distance between two affected tanks at a desired $1,325 \mathrm{~L} / \mathrm{min}(350 \mathrm{gal} / \mathrm{min})$ flow rate.

\subsection{DILUTION AND/OR CHEMICAL ADJUSTMENT}

Dilution of tank waste can be accomplished by the installation of dilution water lines either into the tank contents or the transfer pump suction. This dilution system is installed to achieve optimum performance of the transfer pump and to meet waste transfer performance constraints (i.e., solids content).

Chemical adjustment of the DST waste is accomplished by means of a system that receives vendor deliveries. An offloading pad is provided for staging the bulk chemical trucks (caustic).

The new system will utilize a staging tank for storage of caustic solution. This staging tank will be equipped with a transfer pump for delivery of caustic solution to the process stream. Instrumentation that controls the dilution of vendor deliveries and metered transfer of the solution to the process stream include components such as flow meters, position switches, pressure indicators, conductivity analyzers, temperature indicators, and analog valves. 
A mobile boiler system will be furnished to provide heated dilution water in preparing the caustic solution. Raw water will be supplied to the mobile boiler package. Chemical water treatment in the form of a deionization unit will be provided with the package boiler. Some corrosion control may be required as an additional chemical injection system.

\subsection{MONITOR AND CONTROL SYSTEM}

The pumps and associated components that are being installed are controlled by computer software and hardware. These computer components allow for discrete process signals to be received and transmitted from controllers and operator interface terminals in performing various functions.

The equipment consists of industrial compatible personal computers with the following components: 16 megabytes RAM, 2.5 gigabyte harddrives, and 50.8-cm (20-in.) operator interface (touchscreen), and super VGA monitor, a programmable logic controller and the personal computer interface with a programmable logic controller network for communication.

The operator control interface will be located in the new Instrumentation and Control building.

\subsection{PROJECT ACTIVITY TO EQUIPMENT RELATIONSHIP}

Table 2 illustrates the installation and operations activities associated with waste delivery as related to specific projects or operational level of effort activities. This information helps to identify a precedence of activities which can aid related evaluations of those activity types. Table 2 identifies 6 categories of activities identified as:

- Core Sampling

- Equipment Removal

- Mixer Pump Installations/Construction

- Degas Operations

- Transfer Pump Installation/Construction

- Transfer Operations. 
Table 2. Project Equipment Summary. (2 Sheets)

\begin{tabular}{|c|c|c|}
\hline Activity & Project & Precedence \\
\hline 1. Core sampling & Operations & 241-AN-105 \\
\hline 2. Equipment removal & $\mathrm{W}-211$ & \\
\hline Existing level monitoring & & 241-AY-102,-AZ-101 \\
\hline Existing transfer pump & & 241-SY-101, -AY-102 \\
\hline Thermocouple trees & & 24I-AZ-101, -AY-102 \\
\hline Jumpers & & 241-SY-101, -AY-102 \\
\hline Disposal of LLCE containers & & 241-AZ-101, -AY-102 \\
\hline 3. Mixer Installations/Construction & W-211 & \\
\hline ENRAF liquid level & & 241-SY-101 \\
\hline New transfer pump & & $241-\mathrm{AY}-102 ?$ \\
\hline New thermocouple tree & & 241-AZ-101 \\
\hline 2 mixer pumps & & 241-AZ-101, -SY-101 \\
\hline Extend 2 risers & & 241-AZ-101 \\
\hline Concrete pad around risers & & 241-AZ-101, W-320 \\
\hline Electrical upgrades for pumps & & 241-AZ-101 \\
\hline Instrument control building & & 241-AZ-101 \\
\hline $\begin{array}{l}\text { Caustic addition and } \mathrm{H}_{2} \mathrm{O} \text { dilution } \\
\text { - New flush line/steam generator }\end{array}$ & & W-320 \\
\hline New jumpers in central pump pit & & 241-AY-102 \\
\hline New cover blocks for central pump pit & & 241-SY-101, W-320 \\
\hline \multicolumn{3}{|l|}{ Expand central pit } \\
\hline Camera system (in tank) & & 241-SY-101 \\
\hline Leak detection upgrades pump pit & & 241-AY-102 \\
\hline Sonic probe & & None \\
\hline Slurry distributors & & 241-AY-102 \\
\hline 4. Degas Operation & Operations & \\
\hline $\begin{array}{l}\text { Release entrapped } \mathrm{H}_{2} \text { of: } \\
\text { a. Operate dilution/receive } \\
\text { b. Sonic probe }+ \text { a. } \\
\text { c. Intermittent mixer runs }\end{array}$ & & 241-SY-101 \\
\hline Operate camera & & 241-SY-101 \\
\hline
\end{tabular}




\section{Revision 0}

Table 2. Project Equipment Summary. (2 Sheets)

\begin{tabular}{|c|c|c|}
\hline Activity & Project & Precedence \\
\hline \multicolumn{3}{|l|}{ 5. Transfer Installation/Construction } \\
\hline $\begin{array}{l}\text { Install new } 3 \text {-in. waste transfer lines: } A N \\
\text { to } A Z, A Z \text { to } A X-B \text { valve pit, } A X-B \\
\text { valve pit to } A-A \text { valve pit }\end{array}$ & W-314 & W-058/cross-site \\
\hline $\begin{array}{l}\text { Provide new jumper manifolds in: AN-A } \\
\text { and B, AZ-02A, AX-A and B, and A-A } \\
\text { and B valve pits }\end{array}$ & W-314 & W-058/cross-site \\
\hline Upgrade leak detection & W-314 & W-058/cross-site \\
\hline Master pump shutdown & & $242-A$ \\
\hline Reroute SN-650 to 102 and $104-\mathrm{AP}$ & W-211 & W-058/cross-site \\
\hline New valve pit & $\mathrm{W}-211$ & W-058/cross-site \\
\hline -3-in. transfer line to $2 \mathrm{AP}$ and $4 \mathrm{AP}$ & W-211 & W-058/cross-site \\
\hline $\begin{array}{l}\text {-3-in. transfer line (stub-out) for HLW } \\
\text { feed delivery to P.C. HLW vit plant }\end{array}$ & W-211 & W-058/cross-site \\
\hline -Leak detection & W-211 & W-058/cross-site \\
\hline -MPS tie-in & W-211 & W-058/cross-site \\
\hline -Waste transfer instrumentation & W-211 & W-058/cross-site \\
\hline 6. Transfer Operation & Operations & \\
\hline Set transfer route valve settings & & $\begin{array}{l}\text { Manual - A-Farm } \\
\text { MOV - None }\end{array}$ \\
\hline Operate mixer fulltime & & None \\
\hline Heated caustic/ $\mathrm{H}_{2} \mathrm{O}$ addition to pump inlet & & None \\
\hline Turn transfer pump on recirc & & A-Farm DSTs \\
\hline Transfer to $2 / 4 \mathrm{AP}$ & & A-Farm transfers/242-A \\
\hline Water flush & & $\begin{array}{l}\text { A-Farm/242-A/SW } \\
\text { pumps }\end{array}$ \\
\hline
\end{tabular}

Each of these categories is broken down into subtasks. These subtasks identify the aspects of each category which are within the scope of a given project of operations activity to implement. The referenced projects are used as a model to highlight a precedence for the specific activity. All the activities can be related directly to the projects identified in Section 5.0. 
HNF-SD-TWR-TM-001

Revision 0

\subsection{FEED STAGING OPERATIONS}

Feed staging is outlined in the respective feed staging plans associated with HLW and LAW respectively. These activities revolve around the concept of delivering waste feed to the Phase I Private Contractor facility(s).

The following concepts would be considered with respect to operating the equipment described above.

\subsection{MIXER PUMP OPERATIONS}

Mixer pumps are remotely controlled by a monitor and control system (MCS). This system is a computer operated interface between the operations personnel and the remotely mounted equipment.

The mixer pumps would be monitored for height, run/stop status, speed, nozzle position, power consumption, and bearing temperature.

\subsection{TRANSFER PUMP OPERATIONS}

Transfer pumps are remotely controlled by the same MCS system as discussed with the mixer pump. These pumps are identified with two separate operating scenarios. The first scenario is with in-line dilution and the second is with in-tank dilution.

The transfer pump will be monitored for height, run/stop status, speed, discharge flow rate, discharge pressure, and isolation valve status.

If the transfer pump is equipped with in-line dilution, the dilution ration will be displayed. Transfer pump discharge would also be monitored to obtain optimum performance. The monitored parameters would include pressure, viscosity, density, flow, and temperature of the waste discharge stream.

\subsection{DOUBLE-SHELL TANK OPERATIONS}

The DST in question will be connected to the MCS and monitored for an overview of mixer pump status, transfer pump status, dome pressure, tank temperature, and waste level. 


\section{Revision 0}

\subsection{PIPING CONFIGURATION OPERATIONS}

The transfer path of tank waste is controlled remotely through the MCS system. Pipe routings are monitored via signals received from the applicable valve pits, pump pits, and flush pits. These signals are sent to a common graphics screen for monitoring and control.

\subsection{CHEMICAL ADJUSTMENT OPERATIONS}

Chemical adjustment components are operated/monitored both remotely and locally. Chemical shipments are received at an unloading pad. These chemicals are pumped through a static mixer that blends the chemicals to a predetermined concentration and delivers the solution to a receiving tank for interim storage. The chemical shipments are operated remotely by control of the offloading pump and associated isolation valves. Operator control is required for the physical connection of the delivery truck to the system piping.

Flow rates of the delivered chemicals are monitored for blending. Remote temperature indication is monitored to prevent freezing of chemical solutions in piping components.

Valve positions are controlled through the MCS and real time analytical instruments (i.e., conductivity, $\mathrm{pH}$ ) provide remote readings.

\subsection{MONITOR AND CONTROL SYSTEM OPERATIONS}

The functions of the MCS are to interface with operations personnel to control the functions of an individual process component in a manual mode or the system as a whole in an auto or semi auto mode of operation. The following are the basic functions of the MCS as a whole.

- Monitor and display the status and performance of each selected tank retrieval system (TRS) process subsection and or component group.

- Provide a signal interface to the Hanford Local Area Network (HLAN) for remote monitoring (if required).

- Adjustment of control set points by operations.

- Audible and visual annunciation of alarm conditions.

- Indication of real time, calculated and historical parameters.

- Auto/Manual control of equipment.

- Provide computer controllers to implement analog logic. 
HNF-SD-TWR-TM-001

Revision 0

\subsection{PROJECT DESCRIPTIONS AND INTERFACES}

An overview of project activities is illustrated in Figure 9. A table of relevant project documentation is included as Appendix B.

\subsection{SUPPORT AND INFRASTRUCTURE PROJECTS}

Utilities are to be provided by the currently identified projects:

- W-503, Electrical Systems

- W-504, Raw and Potable Water System Extensions

- W-505, Site Development and Roads

- W-506, Liquid Effluent Transfer Piping.

These projects are required by the TWRS Privatization Contracts (DOE-RL 1996a,b) to provide certain functions in support of the Private Contractors facilities.

\subsubsection{Electrical Systems (W-503)}

Interface description 11 of the TWRS Privatization Contracts specifies the contractor shall specify to DOE the amount of $\mathrm{AC}$ power (average and peak loads) required for its process.

The DOE will provide delivery and maintenance of up to $20 \mathrm{MW}$ of power at the defined capacity. This power will be delivered to the contractor's site perimeter. All power consumption will be monitored by the DOE.

Project W-503 will provide the required power to the Contractor's site through a new $230-13.8 \mathrm{KV}$ substation $1.25 \mathrm{~km}(0.78 \mathrm{mi})$ east of the 200 East Area perimeter, two $230 \mathrm{KV}$ transmission lines approximately $5.5 \mathrm{~km}(3.43 \mathrm{mi})$, each connected to an existing site system to form a loop through the new substation, and a $13.8 \mathrm{KV}$ distribution system extending from the substation to the privatization facilities' perimeter (from personal communication with R. J. Parazin).

\subsubsection{Raw and Potable Water (W-504)}

Interface Description 1 and 2 address the delivery of Raw and Potable Water respectively. 


\section{HNF-SD-TWR-TM-001 \\ Revision 0}

The contractors are required to specify to DOE the amount of raw water required at their respective facilities, connect to the DOE supplied source for raw water and maintain systems within their facilities boundary. The DOE will provide and maintain delivery to the perimeter of the contractors site, up to $760 \mathrm{~L} / \mathrm{min}(200.8 \mathrm{gal} / \mathrm{min})$ of raw water to be used as process water in addition to $9,450 \mathrm{~L} / \mathrm{min}(2,497 \mathrm{gal} / \mathrm{min}$ ) to be used as fire water (shared among the Private contractors).

Contractors are also required to identify the required usage of potable water for their respective facilities, connect to the DOE provided source and maintain the systems within their facilities boundaries.

The DOE will provide and maintain delivery to the perimeter of the contractor's site, up to $95 \mathrm{~L} / \mathrm{min}(25.1 \mathrm{gal} / \mathrm{min})$ of potable water.

These water systems will be provided through the extension and upgrading of existing 200 East Area water systems. Approximately 3,380 m (11,090 ft) of $300 \mathrm{~mm}$ (12 in.) raw water piping and $1,400 \mathrm{~m}(4,594 \mathrm{ft})$ of $100 \mathrm{~mm}(4 \mathrm{in}$.) potable water piping will be extended

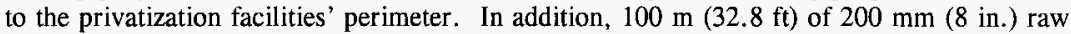
water piping and $700 \mathrm{~m}(2,297 \mathrm{ft})$ of $150 \mathrm{~mm}(6 \mathrm{in}$.) sanitary (potable) water piping will be replaced/upgraded to assure the service life of the delivery systems. When completed, $760 \mathrm{~L} / \mathrm{min}(201 \mathrm{gal} / \mathrm{min})$ of raw water, and $95 \mathrm{~L} / \mathrm{min}(25.1 \mathrm{gal} / \mathrm{min})$ (average rate) of sanitary (potable) water will be delivered to each privatization facility.

\subsubsection{Site Development and Roads (W-505)}

Interface Description 12 (Roads and Rails) addresses the installation of roads to the contractors facilities. No direct rail service will be provided to the contractor's facilities.

The contractors are required to provide roads within their own site boundaries and identify the demand on existing Hanford Site roads.

The DOE will provide and maintain roads access to and between the contractor's facilities and the existing Hanford Site roads.

The site development task will include a number of tasks including approximately $2.4 \mathrm{~km}(1.5 \mathrm{mi})$ of upgraded and $2.0 \mathrm{~km}(1.25 \mathrm{mi})$ of new roadway construction.

Project W-505 will also provide temporary power and raw water to support construction activities. Temporary utilities include $7 \mathrm{MW}$ of temporary power and $1,500 \mathrm{~L} / \mathrm{min}$ (396 $\mathrm{gal} / \mathrm{min}$ ) of raw water to the construction sites. 


\section{Architecture/Project Allocation} (NOTATIONAL ONLY)

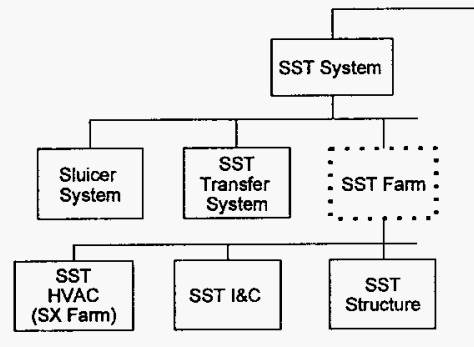

$\cdots \cdots \cdots$
$\vdots$
TwRs
$\ldots$

..
HNF-SD-TWR-TM-001

Revision 0

Figure 9. Proposed Hierarchy Supporting Phase I Privatization.
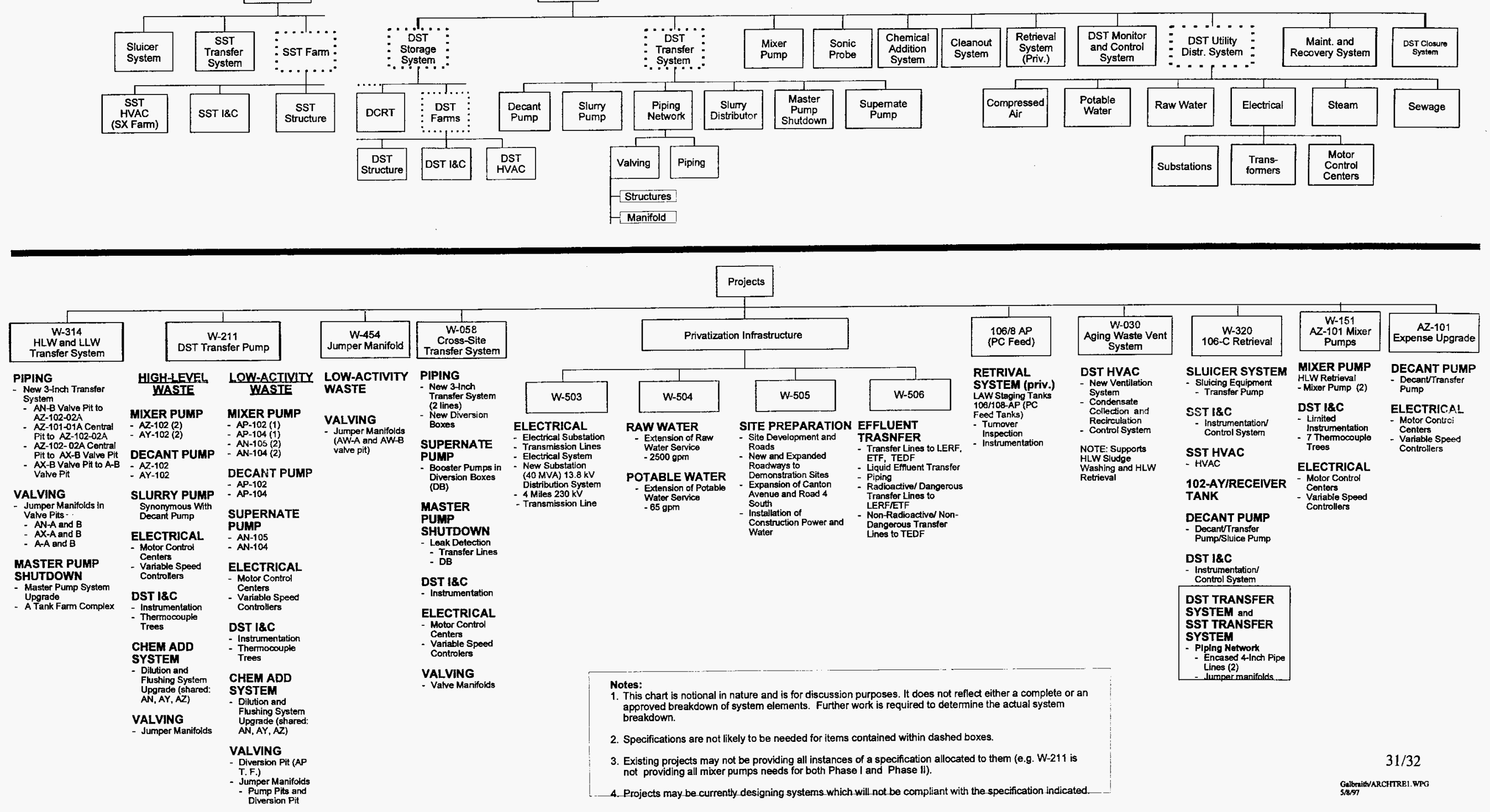
HNF-SD-TWR-TM-001

Revision 0

\subsubsection{Liquid Effluent Transfer Piping (W-506)}

Interface descriptions 5 and 6 address issues related to Non Radioactive Non Dangerous Liquid Effluents and Radioactive Dangerous Liquid Effluents respectively.

Non Radioactive Non Dangerous Liquid Effluents are streams that meet the interface acceptance criteria for discharge directly to the 200 Area Treated Effluent Disposal Facility (TEDF).

The contractors will provide a piping connection to the DOE supplied piping system at their sites boundary.

The DOE has agreed to accept up to $300,000 \mathrm{~m}^{3}\left(10,600,000 \mathrm{ft}^{3}\right)$ per year with an average flow rate of $570 \mathrm{~L} / \mathrm{min}(151 \mathrm{gal} / \mathrm{min})$. This flow will be channeled through newly provided and maintained piping to connect the contractors' facility with the TEDF.

Project W-506 will consist of new piping to be constructed between the privatization contractors' facilities and existing the existing Liquid Effluent Retention Facilities (LERF) and the TEDF. This new piping will be constructed along the east perimeter of the 200 East Area. Non radioactive Non hazardous effluents will be transported to the TEDF by approximately $1,180 \mathrm{~m}(3,872 \mathrm{ft})$ of $75 \mathrm{~mm}$ ( $3 \mathrm{in}$.) pipeline to the existing collection system for TEDF. Hazardous effluents will be transported to the LERF for subsequent treatment at the 200 Area Effluent Treatment Facility (ETF) by constructing approximately $1,150 \mathrm{~m}$ $(3,773 \mathrm{ft})$ of $75 \mathrm{~mm}$ ( 3 in.) carrier pipe encased in a $150 \mathrm{~mm}$ (6 in.) containment pipe. The encasement pipe will be equipped with leak detection. The new double contained piping system will be connected to an existing system that originates at the 242-A Evaporator facility and extends north to the LERF.

\subsection{HIGH-LEVEL WASTE/LOW-ACTIVITY WASTE TRANSFER}

\subsubsection{Tank Farm Restoration and Safe Operations (W-314)}

Project W-314 includes instrumentation replacement, ventilation system replacement, piping additions, pit modifications, and electrical power upgrades. The upgrades focus on the DST system in the 200 East Area, but also include SY Tank Farm in the 200 West Area, 244-A and 244-S double-contained receiver tanks (DCRTs), new transfer lines in the 200 East Area, and minor improvements in the SST farms (Boes 1996). The scope of Project W-314 is defined by the Upgrade Scope Summary Report (Jacobson 1997). The Upgrade Scope Summary Report was prepared as part of a systems engineering process. It defines the scope items (including systems, subsystems, and/or components) to be upgraded. The Upgrade Scope Summary Report was included in the Project W-314 baseline as a key element to define the scope on which to develop the conceptual design report. 


\section{HNF-SD-TWR-TM-001 \\ Revision 0}

A summary of the W-314 scope is presented as the follows. Piping scope includes cleaning, decontaminating, and upgrading piping by the application of protective coating to meet established decontaminability and/or regulatory compliance criteria.

New manifold jumper arrangements shall be installed in selected valve and pump pits to provide a greater degree of flexibility in transfer routes, reduce jumper change out and maintenance requirements, and minimize personnel exposure.

New transfer lines compatible with the new cross site transfer line (W-058) and waste disposal privatization needs will be provided to support projected waste transfer operations. This includes replacement of some existing transfer lines.

Installation of a new diversion box will provide the east termination point for the cross site transfer lines, incorporate overpressure protection for the cross site transfer lines, facilitate installation of new transfer lines to AN-A and AN-B valve pits, and provide an installed rigid jumper and connections to enable cross site transfers to go directly to tank 241-AN-103. In addition, this diversion box will provide the ability to transfer waste into the cross site transfer lines from East Tank Farms.

Also, the waste transfer lines to 244-A DCRT will be permanently be capped.

Ventilation system upgrades are summarized by the following. Upgrades are planned for the primary ventilation systems for DSTs in AN, AP, and AW Farms. The ventilation system for 244-S DCRT will be included. The ventilation systems will include seal pot, drainage systems, and filtration systems. These systems will be modular in design.

Instrumentation and control systems include new and/or upgraded instrumentation monitoring for all DSTs and the 244-S DCRT, tank waste transfer leak detection system upgrades.

Electrical scope includes upgrades to electrical equipment and wiring, as outlined in Upgrade Scope Summary Report (Jacobson 1997) for DSTs, selected SSTs, and the 244-S DCRT.

Assumptions for the above activities are identified in the Upgrade Scope Summary Report.

\subsubsection{AW Jumper Manifold Upgrade (W-454)}

All currently scheduled and future waste transfer operations at the 241-AW Tank Farm, 241-AP Tank Farm, and Evaporator Building 242-A are routed through Valve Pits 241-AW-A and 241-AW-B. Under the current operational mode, each time a different waste transfer route is required, valve pit coverblocks are removed, an individual jumper is physically disconnected, a different jumper is installed and the desired waste transfer piping 
configuration is obtained. The coverblocks are then reinstalled and operations proceed. This method of aligning waste transfer piping requires entry into the valve pit with each evolution (Mattichack 1996).

Project W-454 will install valve manifold assemblies that provide all necessary waste routing configurations by remote manual operation of valve handles that extend through the pit coverblocks. The upgrades provided by Project W-454 will allow the use of all waste transfer piping presently routed to Valve Pits 241-AW-A and 241-AW-B without pit entry or installation and/or removal of additional jumpers. The ability to connect new equipment to the manifold in the future will also be provided.

The valve manifold for each pit will consist of two- and three-way stainless steel ball valves, valve extension handles, lifting bails, valve funnel assemblies, piping, and structural support.

Jumpers will be fabricated to connect each active pit nozzle to the valve manifold. Jumpers will be equipped with the standard plutonium-uranium extraction (PUREX) type connectors. Thirteen jumpers will be required for valve pit 241-AW-A and fifteen jumpers for pit 241-AW-B.

Existing coverblocks will be inspected to determine if they can be modified (drilled) to accept new valve handles that extend through the blocks. Flow diagrams that depict the flow paths are to be painted on the outside surface of the coverblocks. Lock tabs for the valve handles are to be provided on the coverblocks for lock and tagging of transfer lines SL-168 and V-021 (valve pit 241-AW-A) and lines SL-167, V-022, and V-023 (Valve Pit 241-AW-B).

\subsection{HIGH-LEVEL WASTE/LOW-ACTIVITY WASTE RETRIEVAL AND STAGING}

\subsubsection{Initial Tank Retrieval Systems (W-211)}

Project W-211, Initial Tank Retrieval Systems (ITRS), will provide systems for the retrieval of radioactive wastes stored in ten underground DSTs. The tanks contain supernatant liquids over layers of solids that have settled to the bottom. To retrieve wastes, the solids and liquids must be mixed prior to transfer to alternative storage, evaporation, pretreatment, or disposal facilities. The ITRS will provide systems to mobilize the settled solids and transfer the wastes out of the tanks. The DSTs also contain existing equipment that will require removal to allow installation of the new mixing and retrieval systems. The use of mixer pumps to mobilize waste is based on successful retrieval operations at other DOE Sites. 


\section{HNF-SD-TWR-TM-001 \\ Revision 0}

The ITRS project was originally developed with watch list DSTs being the highest priority for retrieval, but also included tanks for processing plant feed. Retrieval of ten tanks makes up for the scope of Project W-211. These tanks include: 241-SY-101, 241-SY-103, 241-AW-101, 241-AN-103 through 241-AN-106, 241-AY-102, 241-AZ-102, and 241-AP-101. Under the original plan, tank 241-SY-101 was the first tank to be retrieved. It should be noted that tank 241-SY-101 may not be the first tank scheduled for retrieval.

Some shift in the current list of tanks may be made as a result of continued evaluations. Changes in priorities will cause tanks in the current scope to be replaced with other tanks in support of the new priorities. Tanks that need to be retrieved to support privatization are undefined at this point. Similarly, the tanks that would be displaced from Project W-211 by adding new tanks to the scope are to be determined.

The ITRS scope of work includes the design, procurement, and installation of the following items as required for each tank (Rieck 1995):

- Mixer pump for sludge mobilization.

- Pump(s) for transferring the waste out of the tanks.

- An operator station that includes functions to monitor, alarm, and control the retrieval systems for each tank.

- Instrumentation required to measure the effects and results of mixer pump operation, and the instrumentation that must be replaced to withstand the mixer pump forces.

- Instrumentation to measure the physical characteristics of the waste prior to transfer.

- Instrumentation for leak detection where it is required for environmental compliance.

- An interface with existing instrumentation that is critical to the mixing or transfer process in order to monitor tank waste, shell and vapor space temperatures, and waste tank levels within the tank.

- Equipment and containers for the removal, cleaning, decontamination, transport, storage, and burial of contaminated components and soil.

- Utilities for retrieval operations (e.g., electrical power, water, and telecommunications).

- Site preparation and tank modifications for the installation of equipment. 
HNF-SD-TWR-TM-001

Revision 0

- Dilution capability to bring waste properties into compliance with transfer line specifications.

- Flushing capability for the transfer pump and the transfer piping.

- A camera system to monitor the mixing operation.

- An existing run-in test facility to be used for the Project W-211 mixer and transfer pump testing.

- An existing cold test facility to be used for Project W-211 equipment installation and removal demonstrations.

\subsubsection{Tank 241-C-106 Retrieval (W-320)}

The purpose of the Tank 241-C-106 Waste Retrieval Sluicing System is to simultaneously slurry the solid waste in 241-C-106 with a sluice stream of supernatant from tank 241-AY-102 (AY-102), and pump the slurry from 241-C-106 to 241-AY-102. In 241-AY-102, the solids will settle from the slurry and the supernatant will be pumped back to $241-\mathrm{C}-106$ as the sluice medium.

A high-volume, low-pressure sluicing method will retrieve, transport, and settle the high-heat waste from Tank 241-C-106 to the 241-AY-102 receiver tank. The sludge from tank 241-C-106 will be converted to slurry buy solution sprayed from the sluicing nozzles. A pump transfers the slurry to the 241-AY-102 receiver tank where the heavy solids will settle and the lighter supernatant will be recirculated as sluicing liquid to tank 241-C-106. Two 10-cm (4-in.) diameter encased pipelines will be provided to transfer slurry and sluicing fluids between tanks 241-C-106 and 241-AY-102 (Bailey 1993).

A combination of wet scrubber/metallic high-efficiency particulate air (HEPA)/charcoal filtration systems are designed to prevent the spread of gaseous and or radioactive particulate contamination to the outside atmosphere. The exhaust gases from tank 241-C-106, including approximately $14 \mathrm{~m}^{3} / \mathrm{min}\left(500 \mathrm{ft}^{3} / \mathrm{min}\right)$ bleeding in from $241-\mathrm{C}-105$ via the cascade line connecting the two tanks, will be monitored to ensure that the exhaust at the stack meets as low as reasonably achievable (ALARA) principles and State and Federal regulatory requirements. Portions of the old exhaust ducting will be capped off and/or removed to facilitate installation of new heating, ventilating, and air conditioning (HVAC) equipment. The new exhaust system will use the existing exhaust riser R-2.

The variable speed sluice pump in tank 241-AY-102 will provide the supernate liquid used for the supernate nozzles located in 241-C-106. The sluice pump will deliver $1,325 \mathrm{~L} / \mathrm{min}$ ( $350 \mathrm{gal} / \mathrm{min}$ ) of supernate to the sluicer nozzle. The transfer line delivering supernate to the sluicing nozzle will be $10-\mathrm{cm}(4-\mathrm{in}$.) schedule 40 . The $10-\mathrm{cm}$ (4-in.) pipe is inside a $15-\mathrm{cm}(6-i n$.$) encasement.$ 
Slurry pumps are actually two pumps in series. One pump is a centrifugal, direct drive, end suction, $40 \mathrm{hp}$ immersible pump installed in the 91-cm (36-in.) riser "R-9" located in pump pit 241-C-06A. The immersible slurry pump feeds a $250 \mathrm{hp}$, vertical direct drive, variable speed, centrifugal slurry booster pump also located in pump pit 241-C-06A. The minimum booster pump speed is about $700 \mathrm{rpm}$. Together, the immersible slurry pump and slurry booster pump are rated to deliver $1,300 \mathrm{~L} / \mathrm{min}(350 \mathrm{gal} / \mathrm{min})$ at $195 \mathrm{~m}(640 \mathrm{ft})$, operating at a temperature of $49^{\circ} \mathrm{C}\left(120^{\circ} \mathrm{F}\right)$ with a structural design temperature of $82^{\circ} \mathrm{C}$ $\left(180^{\circ} \mathrm{F}\right)$. At low solids loading, the pumps are capable of significantly higher flow rate. The immersible pump is equipped with a heavy gauge, $0.6 \mathrm{~cm}(1 / 4-$ in) mesh screen to keep out large particles. The immersible pump height can be adjusted from the control station to allow for slurry elevation changes, and to maintain suction head pressure to operate in the heavy slurry (May 1996).

The sluice pump is identical to the slurry pump except the sluice pump is longer and the riser flange details are different. Like the slurry pump the sluice pump is actually two pumps in series and delivers clarified supernatant to the sluicer nozzle in 241-C-106. The immersible sluice pump is a direct drive, end suction, $40 \mathrm{hp}$ pump installed in the $86-\mathrm{cm}$ (34-in.) riser R-10C located in the sluice pit 241-AY-02E. The immersible sluice pump feeds the centrifugal sluice booster pump in sluice pit AY-02E. The booster pump is a $250 \mathrm{hp}$ vertical direct drive, variable speed pump. The minimum booster pump speed is about $700 \mathrm{rpm}$. The immersible sluice pump and sluice booster have a combined capacity of $1,300 \mathrm{~L} / \mathrm{min}(350 \mathrm{gal} / \mathrm{min})$ at $177 \mathrm{~m}(580 \mathrm{ft})$, an operating temperature of $82{ }^{\circ} \mathrm{C}\left(180^{\circ} \mathrm{F}\right)$. The immersible sluice pumps suction height is regulated by a remotely adjustable winch to maintain the required net positive suction head. The suction inlet of the immersible sluice pump is protected by a heavy gage, 0.6-cm (1/4-in.) mesh screen.

\subsubsection{Hanford Tank Initiative Retrieval Demonstration Project Retrieval System}

Capability of retrieving some waste types by hydraulic sluicing is uncertain. Previously, a sluicing process was used that was not entirely effective on hard-packed solids (referred to as a hard heel). Also unknown is whether tank farms may be closed with residual waste in compliance with applicable environmental regulations, even if the percentage of waste retrieved complies with the Hanford Federal Facility Agreement and Consent Order (Tri-Party Agreement) (Ecology et al. 1994) milestone.

There is significant program risk unless retrieval performance requirements are defined and retrieval systems are developed and deployed before contractor bids are solicited for the retrieval scope of the TWRS privatization program (termed "Phase II privatization"). Phase II privatization is tentatively planned for approximately 2002. The mission of the Hanford Tanks Initiative (HTI) is to minimize these programmatic uncertainties and associated risks by employing the technologies and methods to perform the following:

- Retrieve difficult-to-remove hard-heel waste from a SST 
- Retrieve waste from a SST that has been categorized as having leaked

- Establish retrieval performance criteria

- Characterize waste to measure compliance with retrieval performance criteria

- Provide a basis for future National Environmental Policy Act of 1969 (NEPA), safety, and regulatory actions affecting waste retrieval and operable unit closure for tank farms.

Activities that support the retrieval of hard-heel waste from tank 241-C-106 and readying the tank for closure include the control and monitoring of waste retrieval operations and the storage and containment of tank contents during the waste retrieval. These activities will be performed throughout the project--from the time the tank is being prepared for waste retrieval to retrieval system installation, through waste retrieval to removal of the retrieval system from the tank and its disassembly.

A separate project, Project W-320 to sluice soft-sludge waste from tank 241-C-106, will provide the supporting systems, facilities, and ancillary equipment for retrieving waste from tank 241-C-106. At the completion of sluicing operations, an evaluation will be made of the amount of waste remaining and its physical and chemical characteristics. Equipment remaining in the tank after sluicing operations will be used to the maximum extent possible for hard-heel waste removal.

The scope of the HTI hard-heel waste retrieval activities includes the following (May 1997):

- Provide an integrated waste retrieval system and other equipment to support retrieval of hard-heel waste from tank 241-C-106, as needed to ready that tank for closure

- Upgrade and modify tank structures and utilities, as required by retrieval operations

- Develop and establish leak detection, monitoring, and mitigation (LDMM) criteria.

\subsubsection{Tank Farms Ventilation Upgrade (W-030)}

The upgrades provided by Project W-030 include replacement of the primary ventilation/cooling system and upgrades to the instrument air supply system, a new standby power system, and new instrument and control center. Site improvements and modification or relocation of existing utilities are also included. The facilities that are replaced by the upgrades will be isolated for future decontamination and decommissioning. 


\section{HNF-SD-TWR-TM-001 \\ Revision 0}

The scope of Project W-030 includes the following items. In the AY and AZ Tank Farms Project W-030 will provide (Nordquist 1989):

- Primary tank ventilation and cooling systems

- Instrument air supply and cooling systems

- Instrumentation and controls

- Standby power

- Raw water.

Note:

- New category I structures will have an HVAC system that will heat, cool, and maintain negative pressure as required. These include the standby generator/compressor/service building.

- Building exhaust air passes through a minimum of two stages of HEPA filters. Isokinetic stack sampling and continuous air monitors are provided. The HVAC fans and monitors are equipped with standby power. Also, redundant heating coils, HEPA filters, and exhaust fans will be provided.

The new facilities will be in the area north of the 241-AY and west of 241-AZ Tank Farms. The new process facilities will be arranged to provide ease of operation and maintenance. A new septic tank and sanitary field will be installed for the new changeroom waste effluent. The existing road north of the proposed facility will be relocated approximately $10.7-\mathrm{m}(35-\mathrm{ft})$ northward to provide ease of access to the new process facilities.

The ventilation building will be non-category I. It houses a duplicate MCS and provides personnel restroom and change facilities. It also serves as the access control entry and exit station to the AY and AZ Tank Farms. The ventilation building is equipped with a fire protection system.

The sampling facility consists of a prefabricated metal structure, $7.7-\mathrm{m}(25-\mathrm{ft})$ by $7.7-\mathrm{m}$ $(25-\mathrm{ft})$ by $3-\mathrm{m}(10-\mathrm{ft})$ high with a $2.1-\mathrm{m}(7-\mathrm{ft})$ deep lined receiver sump and weir.

Auxiliary pits (2), a radiation monitor pit, and a diverter pit will be constructed. They are $2.1-\mathrm{m}(7-\mathrm{ft})$ wide by $2.1-\mathrm{m}(7-\mathrm{ft})$ deep and covered on the interior surface with a special protective coating.

A condensate receiver tank, with containment vault and pump pits will be category I structures. The vault and pump pit are constructed of cast in place reinforced concrete and 


\section{HNF-SD-TWR-TM-001 \\ Revision 0}

will be approximately $7.7-\mathrm{m}(25-\mathrm{ft})$ by $7.7-\mathrm{m}(25-\mathrm{ft})$ by $7.7-\mathrm{m}(25-\mathrm{ft})$ deep. The condensate tank has a $13,210-\mathrm{m}^{3}(50,000$-gal) capacity and will be constructed of stainless steel. The tank and vault will be tied in to the primary ventilation system. The vault will have a sump, leak detection, and liner.

A standby power system will include a $1,000 \mathrm{kVA}$ diesel driven generator with automatic transfer switch, service distribution switchboard, two motor control centers, transformers, lighting, and power. MCS.

Uninterruptible power supply (UPS) is provided to maintain continuous power of the

An impressed current cathodic protection system provides corrosion protection for all new underground piping and tanks.

\subsubsection{Mixer Pump System (W-151)}

Mixer pumps (2) will be installed into AZ-101 to demonstrate the ability to mobilize tank sludges. The function of the mixer pump is to support in-tank sludge washing (refer to Manuel et al. 1996).

The mixer pumps suction is positioned near the bottom of the pump and discharge horizontally through two diametrically opposed nozzles at elevations just above the pump suction. The pumps are equipped with variable frequency drive controllers that are adjusted according to operational requirements.

Project W-151 provides for the installation of the mixer pumps, associated controls, thermocouples for temperature monitoring, and additional limited instrumentation (Kidder 1990)

\subsubsection{Immobilized Low-Level Waste Interim Storage (W-465)}

This project is still in the early stages of development and limited information is available. An Alternatives Generation Analysis Report for Immobilized Low-Level Waste Interim Storage Architecture document was produced in support of the project (Burbank 1996).

In this analysis it was concluded that the most attractive alternative is utilizing the combination of existing waste vaults with the construction of a new facility.

Existing waste vaults were constructed by the former grout program in the late 1980's and early 1990's. The vaults were designed to contain liquid low-level waste in a grouted mixture and serve as a disposal structure for the resulting grouted waste monolith. Five 
HNF-SD-TWR-TM-001

Revision 0

vaults were constructed; one was filled before termination of the program, leaving four empty vaults.

A new facility would be constructed to compliment the existing vaults described above. The new facility would provide a below grade building adjacent to and east of the existing vaults. The new structure would share a common bridge crane with the vault. It is suggested the new building would be similar in construction to the existing vault, but would be about $140-\mathrm{m}$ (459-ft) long, providing storage capacity for an additional 5,000 packages.

Under this combined alternative, existing vaults would be modified first, providing storage capacity for about 4 years of production, during which time the new storage building would be constructed.

\subsubsection{Solidified High-Level Waste Interim Storage (W-464)}

This project is in its early phases of development and is described in Statement of Work For Conceptual Design of Solidified High Level Waste Interim Storage System Project (Calmus 1996).

Much of the design work is expected to include definition of new installations and retrofit modifications to an existing radioactive material storage facility, hereafter referred to as the Spent Nuclear Fuel (SNF) Canister Storage Building (CSB). The SNF project is erecting and outfitting the CSB for storage of SNF stored in the Hanford Site K Basin pools. This will include construction of an operations annex, receipt/transfer service bay (loadin/load-out area), three storage vaults each containing 220 storage tubes (six larger tubes for product canister overpack), an adjunct facility to remove gas and liquid from the spent fuel containers (the Hot Conditioning System [HCS] Annex), and a transportation and handling system capable of providing the service to all the aforementioned building space. The SNF Project will outfit one vault (Vault 1) with carbon steel storage tubes.

The HLW Interim Storage System Project intends to use Vaults 2 and 3 for HLW product storage. This will require installation of new, or retrofit, receipt/transfer/handling systems; addition of storage tubes and tube plugs, impact limiters, inlet/outlet stacks, and provide HLW container overpack capability. Vault 1 of the SNF CSB will contain SNF in passive interim storage during the CSB installation/retrofit activities. 
HNF-SD-TWR-TM-001

Revision 0

\subsection{REFERENCES}

Bailey, J. W., 1993, Tank C-106 Sluicing, Letter Report, WHC-SD-WM-ES-234, Rev. 0, Westinghouse Hanford Company, Richland, Washington.

Boes, K. A., 1996, Conceptual Design Report for Tank Farm Restoration and Safe Operations, Project W-314, WHC-SD-W314-CDR-001, Rev 1, Westinghouse Hanford Company, Richland, Washington.

Calmus, R. B., 1996, Statement of Work for Conceptual Design of Solidified HLW Interim Storage System Project (Phase I), HNF-SD-W464-SOW-001, SGN Eurisys Services Corporation, Richland, Washington.

Certa, P. J., W. H. Grams, C. M. McConville, L. W. Shelton, and E. J. Slaathaug, 1996, Low-Level Waste Feed Staging Plan, WHC-SD-WM-RPT-224, Rev. 0, Westinghouse Hanford Company, Richland, Washington.

DOE-RL, 1996a, TWRS Privatization, CONTRACT, DE-ACO6-RL13309, U.S. Department of Energy, Richland Operations Office and Lockheed Martin Advanced Environmental Systems, Richland, Washington.

DOE-RL, 1996b, TWRS Privatization, CONTRACT, DE-ACO6-RL13308, U.S. Department of Energy, Richland Operations Office and BNFL, Inc., Richland, Washington.

Ecology, EPA, and DOE, 1994, Hanford Federal Facility Agreement and Consent Order, as amended, Washington State Department of Ecology, U.S. Environmental Protection Agency, and the U.S. Department of Energy, Olympia, Washington.

Hanlon, B. M., 1997, Waste Tank Summary Report for Month Ending XX-XX-XX (Xs denote a living document), HNF-EP-0182-106, Lockheed Martin Hanford Corporation, Richland, Washington.

Harmon, B. U., 1997, Conceptual Design Report TWRS Privatization Phase I Liquid Effluent Transfer Systems, Subproject W-506, HNF-SD-W506-CDR-001, DRAFT, Fluor Daniel Northwest, Richland, Washington.

Jacobson, R. W., 1997, Tank Farm Restoration and Safe Operation, Project W-314, Upgrade Scope and Summary Report, WHC-SD-W314-RPT-003, Rev. 2, Lockheed Martin Hanford Corporation, Richland, Washington.

Kidder, R. J., 1990, Tank 101-AZ Waste Retrieval System Project W-151, WHC-SD-W151-CDR-001, Rev. 0, Westinghouse Hanford Company, Richland, Washington. 
Kirkbride, R. A., 1997, TWRS Operation and Utilization Plan, HNF-SD-WM-SP-012, Draft, Numatec Hanford Corporation, Richland, Washington.

Kirkbride, R. A., 1997a, Waste Feed Staging Data Quality Objectives Activity Plan, HNF-SD-WM-AP-043, DRAFT, Numatec Hanford Corporation, Richland, Washington.

Kupfer, M. J., A. L. Boldt, B. A. Higley, K. M. Hodgson, L. W. Shelton, and R. A. Watrous (LMHC), S. L. Lambert, and D. E. Place (SESC), R. M. Orme (NHC), G. L. Borsheim (Borsheim Associates), N. G. Colton (PNNL), M. D. LeClair (SAIC), R. T. Winward (Meier Associates), and W. W. Schulz (W'S Corporation), 1997, Standard Inventories of Chemicals and Radionuclides in Hanford Site Tank Wastes, HNF-SD-WM-TI-740, Rev. 0, (to be issued) Lockheed Martin Hanford Corporation, Richland, Washington.

Manuel, A. F., S. L. Lambert, and G. E. Stegen, 1996, Phase I High Level Waste Pretreatment and Feed Staging Plan, WHC-SD-WM-ES-370, Rev. 1, Westinghouse Hanford Company, Richland, Washington.

Mattichack, R. W., 1996, Conceptual Design Letter Report for Project W-454, AW Jumper Manifold Upgrade, WHC-SD-W454-CDR-001, current revision issued under ECN 603491, Westinghouse Hanford Company, Richland, Washington.

May, T. H., 1996, Tank 241-C-106 Waste Retrieval Sluicing System (WRSS) Operations Manual, WHC-SD-W320-Tl-004, Rev. 0, Westinghouse Hanford Company, Richland, Washington.

May, T. H., 1997, Hanford Tank Initiative Retrieval Demonstration Project Retrieval System Design Concept, HNF-SD-HTI-ES-001, Rev OA, Numatec Hanford Corporation, Richland, Washington.

National Environmental Policy Act of 1969, 42 USC 4321 et seq.

Nordquist, E. M., 1989, Conceptual Design Report Tank Farm Ventilation Upgrade, Project W-030, WHC-SD-W030-CDR-001, Rev. 0, Westinghouse Hanford Company, Richland, Washington.

Orme, R. M., 1995, TWRS Process Flowsheet, WHC-SD-WM-TI-613, Rev. 0, Westinghouse Hanford Company, Richland, Washington.

PHMC, 1996a, Unclassified Operating Specifications for the 24I-AN, $A P, A W, A Y, A Z$, and $S Y$ Tank Farms, OSD-T-151-00007, Rev. H-18, Project Hanford Management Contractor, Richland, Washington. 
HNF-SD-TWR-TM-001

Revision 0

PHMC, 1996b, Unclassified Operating Specifications for Single-Shell Waste Storage Tanks, OSD-T-151-00013, Rev. D-13, Project Hanford Management Contractor, Richland, Washington.

PHMC, 1996c, Operating Specifications for Aging-Waste Operations in 24I-AY and 241-AZ, OSD-T-151-00017, Rev. D-9, Project Hanford Management Contractor, Richland, Washington.

PHMC, 1997, Operating Specifications for Aging-Waste Operations in 241-AY and 241-AZ, OSD-T-151-00030, Rev. B-25, Project Hanford Management Contractor, Richland, Washington.

Rieck, C. A., 1995, Supplement 2 to Title I Design Summary Report, Initial Tank Retrieval Systems Summary Project W-211, WHC-SD-W211-TDR-001, Rev. 0, Westinghouse Hanford Company, Richland, Washington.

Salzano, T. B., E. L. Dalpiaz, and A. N. Palit, 1997, Double-Shell Tank Retrieval System Alternative Generation Analysis Support, HNF-SD-TWR-AGA-002, Draft, Numatec Hanford Corporation, Richland, Washington.

Schreiber, R. D., 1996, Tank Characterization Report for Single-Shell Tank 241-C-106, WHC-SD-WM-ER-615, Westinghouse Hanford Company, Richland, Washington. 
HNF-SD-TWR-TM-001

Revision 0

This page intentionally left blank. 
HNF-SD-TWR-TM-001

Revision 0

APPENDIX A

MID-LEVEL LOGIC

Mid Level Logics are in the process of being developed. As information relative to logics becomes available it will be incorporated into this document. 


\section{HNF-SD-TWR-TM-001}

Revision 0

This page intentionally left blank. 


\section{HNF-SD-TWR-TM-001}

Revision 0

APPENDIX B

\section{PROJECT DOCUMENTATION LISTING}

B-1 
HNF-SD-TWR-TM-001

Revision 0

This page intentionally left blank. 
Table B-1. Project Documentation.

\begin{tabular}{|c|c|c|c|c|c|c|c|c|}
\hline \multirow[b]{2}{*}{$\begin{array}{c}\text { Project } \\
\#\end{array}$} & \multirow[b]{2}{*}{$\begin{array}{l}\text { Project } \\
\text { POC }\end{array}$} & \multicolumn{7}{|c|}{ Document name } \\
\hline & & $\begin{array}{c}\text { Project } \\
\text { Management } \\
\text { Plan }\end{array}$ & FDC/DRD/USSR & $\begin{array}{c}\text { Conceptual } \\
\text { Design Report }\end{array}$ & $\begin{array}{l}\text { Operations } \\
\text { Description' } \\
\text { Manual }\end{array}$ & $\begin{array}{l}\text { USQ/ABR } \\
\text { PSAR, } \\
\text { ASA }\end{array}$ & $\begin{array}{l}\text { Environmental } \\
\text { Review } \\
\text { (NEPA/RCRA/ } \\
\text { CERCLA/ } \\
\text { TSCA) }\end{array}$ & ATP/OTP \\
\hline$W-503$ & Parazin & & & & & & & \\
\hline W-504 & Parazin & & & & & & & \\
\hline W-505 & Parazin & & & & & & & \\
\hline W-506 & Parazin & & & & & & & \\
\hline W-314 & Rutherford & & $\begin{array}{l}\text { WHC-SD-W314- } \\
\text { DRD-001 } \\
\text { WHC-SD-W314- } \\
\text { DRR-001 } \\
\text { WHC-SD-W314- } \\
\text { FRD-001 } \\
\text { HNF-SD-W314- } \\
\text { RPT-003 }\end{array}$ & $\begin{array}{l}\text { WHC-SD- } \\
\text { W314-CDR-001 } \\
\text { WHC-SD- } \\
\text { W314-RPT-003 }\end{array}$ & & & & \\
\hline W-454 & Mattichak & $\begin{array}{l}\text { Candidate } \\
\text { project } \\
\text { support sheet } \\
\text { (CPSS) W- } \\
454 \\
\end{array}$ & $\begin{array}{l}\text { WHC-SD-W454- } \\
\text { FDC-001, ECN } \\
603491\end{array}$ & $\begin{array}{l}\text { WHC-SD- } \\
\text { W454-CDLR- } \\
001, \text { ECN } \\
612972\end{array}$ & & TF-96-0713 & $\begin{array}{l}\text { 01810-RJW- } \\
95-052 \\
\text { 95-POC-033 }\end{array}$ & \\
\hline W-211 & Van Beek & $\begin{array}{l}\text { exists but not } \\
\text { controlled }\end{array}$ & $\begin{array}{l}\text { WHC-SD-W211- } \\
\text { FDC-001 }\end{array}$ & $\begin{array}{l}\text { WHC-SD- } \\
\text { W211-CDR- } \\
001 / 002\end{array}$ & & & TWRS-EIS & \\
\hline $\mathrm{W}-320$ & Bailey & $\begin{array}{l}\text { WHC-SD- } \\
\text { W320-PMP- } \\
\text { 001 }\end{array}$ & $\begin{array}{l}\text { HNF-SD-WM- } \\
\text { FRD-031 }\end{array}$ & & $\begin{array}{l}\text { WHC-SD- } \\
\text { W320-TI-004 }\end{array}$ & & & \\
\hline
\end{tabular}


Table B-1. Project Documentation.

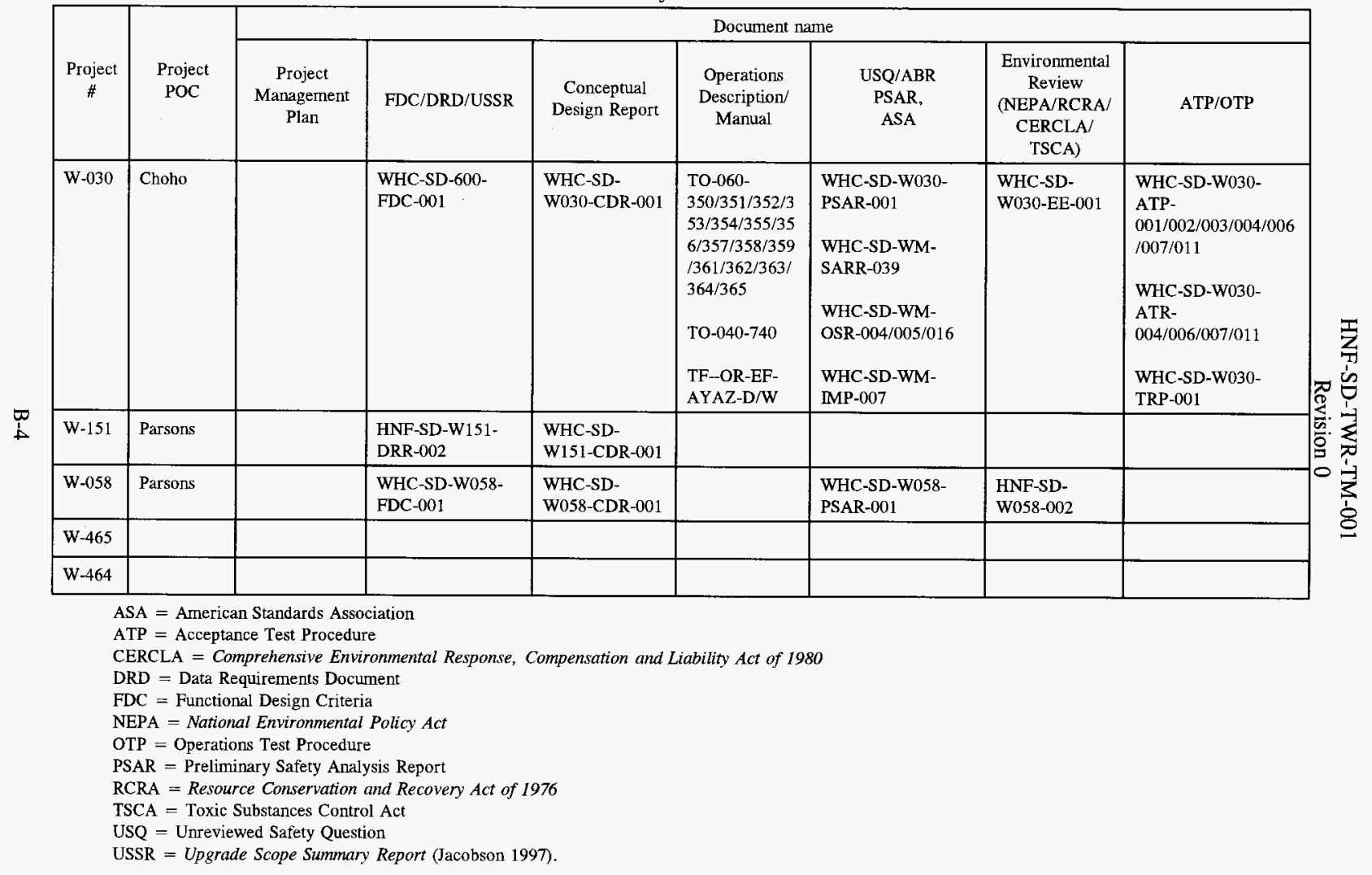




\section{DISTRIBUTION SHEET}

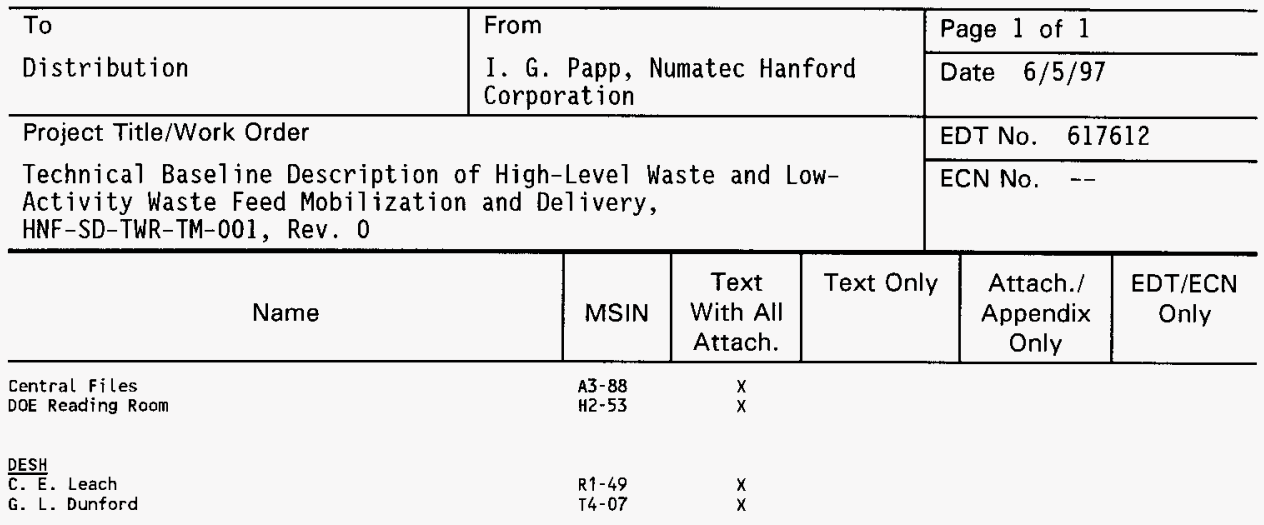

Fluor Daniel Hanford, Inc.

\section{J. Washenfelder}

Lockheed Mart in Hanford Corporation

\section{G. Baide}

J. B. Berry

S. Blacker

L. E. Borneman

D. E. Bowers

T. W. Crawford

B. G. Erlandson

K. A. Gasper

N. W. Kirch

A. F. Manuel

R. J. Murkowsk i

M. J. O'Neill

S. M. O'Toole

R. W. Powell

D. W. Reberger

W. T. Thompson

R. L. Treat

J. A. Yoogd

R. D. Wojtasek

Numatec Hanford Corporation

s7-40 $x$

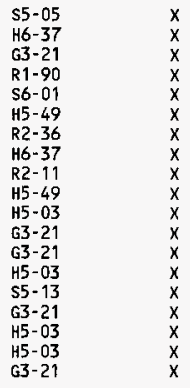

$52-48$

$52-48$

H5-61

H6- 35

$\mathrm{R} 3-47$

H5 -49

H5-61

H5 -49

R $1-49$

H5- 27

H5-61

$\mathrm{R} 3-25$

H5 -49

R3-47

H $5-49$

R3-25

$\$ 2-48$ $x$
$x$
$x$
$x$
$x$
$x$
$x$
$x$
$x$
$x$
$x$
$x$
$x$
$x$
$x$
$x$
$x$
$x$
$x$

$x$
$x$
$x$
$x$
$x$
$x$
$x$
$x$
$x$
$x$
$x$
$x$
$x$
$x$
$x$
$x$
$x$ 